Brit. J. soc. Med. (1947) 1, 251-275

\title{
THE MEDICAL ETHNOGRAPHY OF THE SECOND WORLD WAR \\ BY
}

LANCELOT HOGBEN, F.R.S., MURIEL M. JOHNSTONE, M.A., Ph.D., AND DIANA MULLINGS, B.Sc.

(Received June 12, 1946)

\section{INTRODUCTION}

Except in so far as the occurrence of large-scale epidemics has provided opportunities for differential observation, there is available little well-accredited information concerning the liability of persons of non-European stock to diseases not commonly current in their normal habitat or of the liability of persons of European stock to diseases prevalent in Africa, Asia, and Oceania. This is necessarily so, because of the paucity of statistical machinery in countries which are not as yet highly industrialized and in countries which have no long tradition of occidental medicine. It is therefore unnecessary to expand the ensuing account by reference to current literature or to emphasize at length the peculiar opportunities which Army hygiene offers for a scientific study of this sort. Information about morbidity and mortality with respect to troops of different ethnic origin supplied by Army medical authorities has evidently two outstanding advantages in so far as:

(a) we are in a position to assess with reliability each relevant population at risk;

(b) troops of different ethnic stock live together in a given theatre in a comparatively homogeneous environment.

How far morbidity or mortality differentials disclosed by such statistics are respectively attributable to nature and to nurture is an issue which available data can settle conclusively only in so far as we can compare experiences of troops in one geographical environment with that of troops of the same ethnic group in another. The mere fact that different ethnic groups are differentially susceptible to particular diseases in one and the same environment offers no conclusive evidence for the genetic origin of such differentials, which might well arise from external circumstances antecedent to enlistment. In this context, therefore, an ethnic differential merely signifies an observable difference between individuals of different geographical origin. That it is attributable to nurture may be an assertion justifiable in certain circumstances. The assertion that it is attributable to differences with respect to genetic constitution would in no case be legitimate without recourse to information other than such as our present data disclose. 


\section{SOURCES OF DATA}

The documentary source of the data dealt with below was the crude figures: contained in statistical appendices to Hygiene reports transmitted from Overseas Theatres to the War Office. Army Forms W 3166-7, which have now replaced these appendices, explicitly call for information with respect to colonial troops whose individual documents do not directly reach the War Office Central File of medical documents; but there was no uniform standard of such information available from individual theatres during the first half of the war. Through the foresight of Brigadier Richmond, now Director of Hygiene at the War Office, then Deputy Director at General Headquarters, Cairo, the statistical section of the Middle East Force kept careful records of the morbidity and mortality experience of all troops under British Command stationed in that theatre from 1942 onwards; and two of the writers visited the General Headquarters of the Middle East Force with a view to exploring possible sources of error in the basic demographic data of the reports issued therefrom. Throughout the whole war West Africa Commands. transmitted to the War Office comprehensive reports with respect both to the United Kingdom and to locally recruited African troops. Our data referable to the Italian and North African Campaigns and to troops in the Far Eastern Theatre (A.L.F.S.E.A.) necessarily cover a shorter period of time. For various reasons it has been impossible to check their intrinsic reliability as thoroughly as it has been possible to check those of the Middle East Force; but the extent to which they disclose conclusions consonant with those derived from statistics of M.E.F. and West Africa sufficiently justifies their inclusion in this context.

The introduction of A.F. W 3166-7 by the present Director of Hygiene signalized the rendition of hygiene statistics which classify Army personnel with greater refinement than the earlier reports. With one exception, our data refer to a period antecedent to its introduction. Hence troops designated African in what follows are not wholly comparable. Under this designation statistics from the West Africa commands refer only to locally recruited troops, that is, to the indigenous. populations of British West Africa. A.L.F.S.E.A. statistics post-date the introduction of the new procedure and therefore budget separately troops locally recruited in British West Africa and in British East Africa. Statistics of the Middle East Force (M.E.F.) and of the Central Mediterranean Force (C.M.F.) include as. African troops from both territories, with a preponderance of East Africans in the former. Troops respectively specified as U.K. (i.e. recruited in the United Kingdom) or as Canadian are exclusively of European stock. New Zealand troops. included Maori divisions, and South African troops included divisions with personnel of both African and Asiatic origin. Troops designated Indian signify Asiatic troops locally recruited in British India.

For the reasons stated above, the source of our information with respect to individual diseases antedates adoption of a uniform system of medical taxonomy throughout all commands by the introduction of A.F. W 3166-7. Hence certain 
diagnoses call for preliminary comment. For U.K. troops specialist diagnoses are independently obtainable from the War Office Central File of medical documents; but consolidated returns of different personnel categories from no theatre permit refined separation of the pneumonias or dysenteries. For all theatres except M.E.F. we can broadly separate amoebic and bacillary dysenteries, but for no theatre is it possible to type the bacillary dysenteries, or to judge how many cases reported as diarrhoea represent sub-clinical manifestations of one or other form. Pneumonia signifies pneumonitis and pneumoniasis indifferently, but excludes secondary pneumonia contracted in hospital. Consolidated malaria statistics of two theatres cite separately the three main types (malignant tertian, benign tertian, and quartan); but a firm separation of primary cases from reinfections or relapses is nowhere possible; and the totals cited include cases denominated as such by clinical criteria alone. Gonorrhoea figures present the usual difficulty arising in the early stages of the war from lack of a clear directive (subsequently issued) with respect to explicit rendition of figures referable to G-C positive cases, to G-C negative cases, and to cases for which no smear report is available. Hence it is impossible to assess the precise attenuation of the gross figures through inclusion of non-specific urethtitis. In a contribution to so important a branch of vital statistics the specification of pyrexia of unknown origin would be repugnant, if it did not give us some indication of possible under-estimation of malaria, of sandfly fever, and of dengue fever. It is unfortunate that West African returns, the design of which preceded later interest focused on infective hepatitis epidemicsand hepatitis associated with syphilis therapy or with blood transfusion, etc., seemingly include under one label (jaundice) cases of both the former together with a small proportion of cases of Weil's disease and amoebic hepatitis.

\section{STANDARDIZATION OF RATES}

Basic demographic particulars available for analysis of the crude data include the total number of troops of a given personnel category as specified below in a particular command and its location. Only for U.K. troops have we exact information about the age structure of the population at risk. Hence it is not possible to standardize crude morbidity rates for differences with respect to age composition. We have therefore to interpret any recorded differences with due regard to this familiar pitfall in the light of: $(a)$ the authors' general knowledge of the age-structure of the populations under review; $(b)$ the extent of consequent distortion consistent with fullest allowance for age differences. Having scrutinized what relevant data are accessible, we may say that no differentials to which we here direct attention could conceivably emerge from comparison of the data, if age alone were responsible.

On the other hand, we are in a position to make adjustments dictated by a circumstance which does not commonly arise in compact communities with reliable public statistics of disease. In a theatre such as any which we here discuss, 
physiographic conditions relevant in one way or another to the incidence of disease, especially of communicable diseases such as malaria, venereal disease, or sandfly fever, are highly variable, and sufficient to account for very gross statistical differences between different localities. If troops of one personnel category are largely stationed in one such locality and troops of a second personnel category are concentrated in another, differences solely attributable to differential exposure to risk may thus be spuriously associated with a difference which has no relation to ethnic variables as such. Where available, we have therefore taken advantage of statistics for total strength of troops of different ethnic categories in different commands of the same theatre to apply to our crude figures a method of standardization in principle strictly analogous to age-standardization. Standardized rates here cited thus signify rates computed on the assumption that the geographical distributions of each ethnic group was the same. For this purpose, we usually employ the U.K. distribution as the standard.

In what follows relative morbidity or mortality rates respectively represent the proportionate (percentage) contributions of individual diseases to all diseases or deaths reported for a given category of personnel. Comparative morbidity and mortality rates exhibit respectively the absolute incidence of reported cases of a given disease or of deaths therefrom expressed as a percentage of the corresponding incidence among personnel of the category taken (here always U.K. troops) as the standard. In contradistinction to mortality rates, fatality rates signify deaths. attributable to a given disease as a fraction of reported cases of the disease.

\section{West Africa}

For the quinquennium 1941-45 we have data with respect to two ethnic categories stationed in West Africa, viz. U.K. troops (i.e. of European stock) in an alien habitat and locally recruited African troops indigenous to the same major geographical region.

Our first table, which refers to two levels of general morbidity, serves to emphasize remarks in the concluding paragraphs of the foregoing section, to draw attention to the dominant contribution of malaria, and to bring into relief a striking ethnic differential with respect to its incidence. The right half of the table (invaliding) cites figures for Africans medically discharged from the service and for Europeans no longer fit for service in the theatre. The spectacular steady decline of hospitalized morbidity among troops of European stock throughout the quinquennium is almost entirely, if not wholly, attributable to declining incidence of malaria during a period which witnessed the introduction of mepacrine as a suppressive. No such decline of general morbidity took place among African troops, the lower general morbidity of whom is almost entirely attributable to the very small contribution of malaria. Table II shows how small this contribution was. The only other outstanding differentials sufficiently large to exclude the possibility that they are attributable to age differences, more 
especially in the light of data elsewhere published by Hogben and Johnstone (1947), are venereal disease (all types), dysentery, and chickenpox.

TABLE I

ANNuAl Morbidity Rates Per Thousand: West Africa, 1941-45

(i) Hospital Admissions-all causes (a) U.K. Troops

(ii) Invaliding (a) U.K. Troops

(evacuations to U.K.)

\begin{tabular}{|c|c|c|c|c|c|c|c|c|c|c|c|}
\hline \multirow[b]{2}{*}{ Year } & \multirow{2}{*}{$\begin{array}{l}\text { Gold } \\
\text { Coast }\end{array}$} & \multirow[b]{2}{*}{ Nigeria } & \multirow{2}{*}{$\begin{array}{l}\text { Sierra } \\
\text { Leone }\end{array}$} & \multirow[b]{2}{*}{ Gambia } & \multicolumn{2}{|c|}{$\begin{array}{l}\text { Whole } \\
\text { command }\end{array}$} & \multirow{2}{*}{$\begin{array}{l}\text { Gold } \\
\text { Coast }\end{array}$} & \multirow{2}{*}{ Nigeria } & \multirow{2}{*}{$\begin{array}{l}\text { Sierra } \\
\text { Leone }\end{array}$} & \multirow[b]{2}{*}{ Gambia } & \multirow[b]{2}{*}{$\begin{array}{l}\text { Whole } \\
\text { com- } \\
\text { mand }\end{array}$} \\
\hline & & & & & $\begin{array}{c}\text { All } \\
\text { causes }\end{array}$ & $\begin{array}{c}\text { Minus } \\
\text { malaria }\end{array}$ & & & & & \\
\hline $\begin{array}{l}1941 \\
1942 \\
1943 \\
1944 \\
1945\end{array}$ & $\begin{array}{r}1,737 \\
1,585 \\
1,432 \\
1,029 \\
812\end{array}$ & $\begin{array}{r}968 \\
907 \\
1,186 \\
1,332 \\
794\end{array}$ & $\begin{array}{r}1,804 \\
1,583 \\
1,017 \\
677 \\
644\end{array}$ & $\begin{array}{r}942 \\
1,852 \\
1,161 \\
826 \\
686\end{array}$ & $\begin{array}{r}1,620 \\
1,436 \\
1,157 \\
1,105 \\
760\end{array}$ & $\begin{array}{l}725 \\
674 \\
715 \\
827 \\
668\end{array}$ & $\begin{array}{l}53 \\
44 \\
36 \\
44 \\
55\end{array}$ & $\begin{array}{r}131 \\
95 \\
62 \\
116 \\
58\end{array}$ & $\begin{array}{l}91 \\
69 \\
55 \\
67 \\
64\end{array}$ & $\begin{array}{l}76 \\
54 \\
55 \\
75 \\
62\end{array}$ & $\begin{array}{l}96 \\
70 \\
59 \\
85 \\
59\end{array}$ \\
\hline
\end{tabular}

(b) Africans

(b) Africans (discharge from service)

\begin{tabular}{r|r|r|r|r|r|r|r|r|r|r|r}
\hline 1941 & 877 & 372 & 1,400 & 500 & 632 & 561 & $*$ & $*$ & $*$ & $*$ & $*$ \\
1942 & 811 & 409 & 897 & 881 & 721 & 648 & 59 & 51 & 25 & 25 & 44 \\
1943 & 733 & 654 & 656 & 803 & 663 & 621 & 51 & 43 & 23 & 21 & 37 \\
1944 & 950 & 1,032 & 421 & 852 & 851 & 806 & 52 & 62 & 18 & 34 & 46 \\
1945 & 764 & 647 & 423 & 866 & 649 & 616 & 95 & 140 & 27 & 38 & 100 \\
\hline
\end{tabular}

* Figures not available.

TABLE II

Hospital Admissions 1944 and 1945 with respect, to Certain Infectious Diseases; AnNual Rates Per Thousand: West Africa

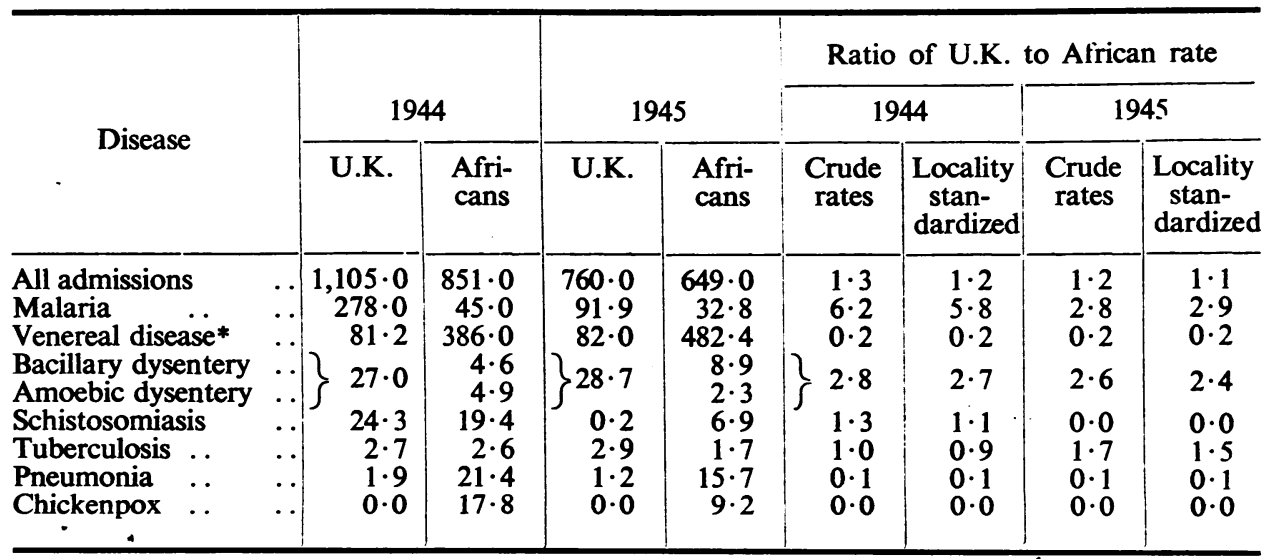

* Includes cases treated in units.

As stated above, our information with respect to dysentery does not entitle us to cite figures for the several types. Since cases recorded as such would refer only 
to patients with mucous stools, figures cited fall far below the total of sickness attributable to the responsible pathogens. For U.K. troops we have access to figures which indicate considerable geographical variation with respect to the ratio of cases of bacillary to amoebic dysentery, as shown by the following consolidated (quinquennial) figures for the different commands:

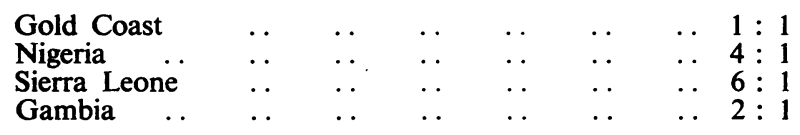

TABLE III

Annual Hospital admissions for Malaria and Dysentery per Thousand Strength; U.K. Troops: West Africa

\begin{tabular}{|c|c|c|c|c|c|c|c|c|c|c|c|c|}
\hline \multirow[b]{3}{*}{ Year } & \multicolumn{6}{|c|}{ (i) Malaria } & \multicolumn{6}{|c|}{ (ii) Dysentery } \\
\hline & \multirow{2}{*}{$\begin{array}{l}\text { Gold } \\
\text { Coast }\end{array}$} & \multirow{2}{*}{ Nigeria } & \multirow{2}{*}{$\begin{array}{l}\text { Sierra } \\
\text { Leone }\end{array}$} & \multirow[b]{2}{*}{ Gambia } & \multicolumn{2}{|c|}{$\begin{array}{l}\text { Whole } \\
\text { Command }\end{array}$} & \multirow{2}{*}{$\begin{array}{l}\text { Gold } \\
\text { Coast }\end{array}$} & \multirow{2}{*}{ Nigeria } & \multirow{2}{*}{$\begin{array}{l}\text { Sierra } \\
\text { Leone }\end{array}$} & \multirow{2}{*}{ Gambia } & \multicolumn{2}{|c|}{$\begin{array}{c}\text { Whole } \\
\text { Command }\end{array}$} \\
\hline & & & & & $\begin{array}{c}\text { Crude } \\
\text { rates }\end{array}$ & $\begin{array}{l}\text { Locality } \\
\text { stan- } \\
\text { dardized }\end{array}$ & & & & & $\begin{array}{c}\text { Crude } \\
\text { rates }\end{array}$ & $\begin{array}{l}\text { Locality } \\
\text { stan- } \\
\text { dardized }\end{array}$ \\
\hline $\begin{array}{l}1941 \\
{[942} \\
1943 \\
1944 \\
1945\end{array}$ & $\begin{array}{r}1,001 \\
810 \\
460 \\
243 \\
74\end{array}$ & $\begin{array}{l}564 \\
525 \\
462 \\
399 \\
139\end{array}$ & $\begin{array}{r}894 \\
754 \\
370 \\
68 \\
61\end{array}$ & $\begin{array}{r}662 \\
1,071 \\
483 \\
175 \\
28\end{array}$ & $\begin{array}{r}895 \\
762 \\
442 \\
278 \\
92\end{array}$ & $\begin{array}{l}895 \\
796 \\
496 \\
290 \\
103\end{array}$ & $\begin{array}{l}28 \\
21 \\
28 \\
36 \\
51\end{array}$ & $\begin{array}{l}25 \\
45 \\
42 \\
13 \\
11\end{array}$ & $\begin{array}{l}46 \\
85 \\
49 \\
24 \\
23\end{array}$ & $\begin{array}{r}117 \\
.53 \\
51 \\
56 \\
33\end{array}$ & $\begin{array}{l}51 \\
71 \\
42 \\
27 \\
29\end{array}$ & $\begin{array}{l}51 \\
61 \\
54 \\
38 \\
42\end{array}$ \\
\hline
\end{tabular}

The importance of locality standardization also receives emphasis from the considerable differences between contemporary malaria, dysentery, and venereal disease rates of troops stationed in the four commands of this theatre (Gold Coast, Nigeria, Sierra Leone, and Gambia) as shown in Tables III, IV, and VI. Table III emphasizes the unequal decline of malaria incidence among British troops in the four territories. The left half of Table IV makes this inequality more explicit,

TABLE IV

Hospital Admission Rates for Malaria, West Africa 1942-45, as Percentage of 1941 Rates

\begin{tabular}{|c|c|c|c|c|c|c|c|c|c|}
\hline \multirow{3}{*}{ Year } & & \multicolumn{4}{|c|}{ U.K. Troops } & \multicolumn{4}{|c|}{ Whole command } \\
\hline & & \multirow{2}{*}{$\begin{array}{l}\text { Gold } \\
\text { Coast }\end{array}$} & \multirow[b]{2}{*}{ Nigeria } & \multirow{2}{*}{$\begin{array}{l}\text { Sierra } \\
\text { Leone }\end{array}$} & \multirow[b]{2}{*}{ Gambia } & \multicolumn{2}{|c|}{ Crude rates } & \multicolumn{2}{|c|}{$\begin{array}{c}\text { Locality standard- } \\
\text { ized rates }\end{array}$} \\
\hline & & & & & & $\begin{array}{l}\text { U.K. } \\
\text { Troops }\end{array}$ & Africans & $\begin{array}{l}\text { U.K. } \\
\text { Troops }\end{array}$ & Africans \\
\hline $\begin{array}{l}1941 \\
1942 \\
1943 \\
1944 \\
1945\end{array}$ & $\begin{array}{l}\ldots \\
\ldots \\
\cdots \\
\ldots\end{array}$ & $\begin{array}{r}100 \cdot 0 \\
86 \cdot 9 \\
46 \cdot 0 \\
24 \cdot 3 \\
7 \cdot 4\end{array}$ & $\begin{array}{r}100 \cdot 0 \\
93 \cdot 1 \\
81 \cdot 9 \\
70 \cdot 7 \\
24 \cdot 6\end{array}$ & $\begin{array}{r}100 \cdot 0 \\
76 \cdot 6 \\
37 \cdot 6 \\
6 \cdot 9 \\
6 \cdot 8\end{array}$ & $\begin{array}{r}100 \cdot 0 \\
161 \cdot 2 \\
73 \cdot 0 \\
26 \cdot 4 \\
4 \cdot 2\end{array}$ & $\begin{array}{r}100 \cdot 0 \\
85 \cdot 1 \\
49 \cdot 4 \\
31 \cdot 1 \\
10 \cdot 3\end{array}$ & $\begin{array}{r}100 \cdot 0 \\
102 \cdot 8 \\
59 \cdot 2 \\
63 \cdot 4 \\
46 \cdot 5\end{array}$ & $\begin{array}{r}100 \cdot 0 \\
88 \cdot 9 \\
55 \cdot 4 \\
32 \cdot 4 \\
11 \cdot 5\end{array}$ & $\begin{array}{r}100 \cdot 0 \\
52 \cdot 6 \\
47 \cdot 4 \\
47 \cdot 4 \\
33 \cdot 7\end{array}$ \\
\hline
\end{tabular}


and shows that the total decline of the incidence of malaria among African troops starting at a much lower initial level was proportionately less though initially steeper. Whether this difference is wholly or partly attributable to better mepacrine

TABLE V

Cases of Blackwater Fever per Thousand Cases of Malaria: U.K. Troops; West Africa 1941-1945

\begin{tabular}{c|c|c|c|c|c}
\hline Year & $\begin{array}{c}\text { Gold } \\
\text { Coast }\end{array}$ & Nigeria & $\begin{array}{c}\text { Sierra } \\
\text { Leone }\end{array}$ & Gambia & $\begin{array}{c}\text { Whole } \\
\text { command }\end{array}$ \\
\cline { 2 - 5 } 1941 & $8 \cdot 4$ & $11 \cdot 5$ & $3 \cdot 5$ & 16.0 & 6.0 \\
1942 & 13.0 & 23.0 & 5.0 & 8.0 & 13.0 \\
1943 & 11.0 & 10.0 & 6.0 & 8.0 & $9 \cdot 0$ \\
1944 & 1.5 & 0.5 & - & - & 1.0 \\
1945 & - & - & - & - & - \\
\hline
\end{tabular}

morale among U.K. troops is a question for which our data provide no solution. The suppressive doses actually employed in the theatre were as follows:

\begin{tabular}{|c|c|c|}
\hline $\begin{array}{l}\text { Janu } \\
\text { Mar }\end{array}$ & & $\begin{array}{l}\text { Quinine grs. V daily } \\
\text { Mepacrine } 0.4 \text { g. per week }\end{array}$ \\
\hline 1944 & & \\
\hline & & $0.7 \mathrm{~g}$. \\
\hline
\end{tabular}

In all commands (Table VI) the incidence of venereal disease among Africans was much higher than among U.K.troops, at least three and a half times as high in Nigeria in 1943 and fifteen times as high in the Gambia during 1945. The proportionate contributions of the several venereal diseases to the total venereal disease rate, as shown in Table VII, is subject to considerable variation chronologically

TABLE VI

Annual Venereal Disease (all Types) Rates per Thousand: West Africa

\begin{tabular}{|c|c|c|c|c|c|c|c|c|c|c|c|c|}
\hline \multirow{3}{*}{ Year } & \multirow{2}{*}{\multicolumn{2}{|c|}{ Gold Coast }} & \multirow{2}{*}{\multicolumn{2}{|c|}{ Nigeria }} & \multirow{2}{*}{\multicolumn{2}{|c|}{ Sierra Leone }} & \multirow{2}{*}{\multicolumn{2}{|c|}{ Gambia }} & \multicolumn{4}{|c|}{ Whole c ommand } \\
\hline & & & & & & & & & \multicolumn{2}{|c|}{ Crude rates } & \multicolumn{2}{|c|}{$\begin{array}{l}\text { Locality } \\
\text { standardized }\end{array}$} \\
\hline & U.K. & Afr. & U.K. & Afr. & U.K. & Afr. & U.K. & Afr. & U.K. & Afr. & U.K. & Afr. \\
\hline $\begin{array}{l}1941 \\
1942 \\
1943 \\
1944 \\
1945\end{array}$ & $\begin{array}{l}71 \\
62 \\
65 \\
69 \\
83\end{array}$ & $\begin{array}{c}* \\
319 \\
300 \\
419 \\
491\end{array}$ & $\begin{array}{r}37 \\
48 \\
106 \\
110 \\
85\end{array}$ & $\begin{array}{c}* \\
475 \\
359 \\
477 \\
537\end{array}$ & $\begin{array}{l}52 \\
42 \\
39 \\
46 \\
89\end{array}$ & $\begin{array}{c}* \\
172 \\
196 \\
280 \\
325\end{array}$ & $\begin{array}{l}24 \\
16 \\
21 \\
22 \\
41\end{array}$ & $\begin{array}{c}* \\
86 \\
102 \\
120 \\
614\end{array}$ & $\begin{array}{l}52 \\
45 \\
69 \\
81 \\
82\end{array}$ & $\begin{array}{c}* \\
314 \\
296 \\
386 \\
482\end{array}$ & $\begin{array}{l}52 \\
49 \\
70 \\
75 \\
81\end{array}$ & $\begin{array}{c}* \\
325 \\
321 \\
387 \\
475\end{array}$ \\
\hline
\end{tabular}

* Figures not available.

and locally. No consistent difference between the two types of personnel emerges from the figures for 1944 and 1945 . For correct assessment of the contents of this Table, it is necessary to give weight to the following considerations:

(a) 1945 figures for gonorrhoea are not strictly comparable with those of preceding years, in so far as they record separately G-C negative cases or cases for which no smear report is available. In contradistinction to rates cited for 
TABLE VII

Rei ative Rates with respect to Venereal Disease: West Africa 1944, 1945

\begin{tabular}{|c|c|c|c|c|c|c|c|c|}
\hline \multirow[b]{2}{*}{1944} & \multicolumn{2}{|c|}{ Gold Coast } & \multicolumn{2}{|c|}{ Nigeria } & \multicolumn{2}{|c|}{ Sierra Leone } & \multicolumn{2}{|c|}{ Gambia } \\
\hline & U.K. & Afr. & U.K. & Afr. & U.K. & Afr. & U.K. & Afr. \\
\hline $\begin{array}{lll}\text { Syphilis } & . . & . . \\
\text { Gonorrhoea } & . & . \\
\text { Lymphogranuloma } & \\
\text { inguinale } & . . & . \\
\text { Chancroid } & . . & . .\end{array}$ & $\begin{array}{r}8 \cdot 4 \\
72 \cdot 8 \\
7 \cdot 0 \\
11 \cdot 8\end{array}$ & $\begin{array}{r}2 \cdot 3 \\
76 \cdot 6 \\
11 \cdot 3 \\
9 \cdot 8\end{array}$ & $\begin{array}{r}4 \cdot 1 \\
59 \cdot 2 \\
8 \cdot 8 \\
27 \cdot 9\end{array}$ & $\begin{array}{r}2 \cdot 1 \\
92 \cdot 0 \\
\\
3 \cdot 5 \\
2 \cdot 4\end{array}$ & $\begin{array}{r}18 \cdot 0 \\
70 \cdot 0 \\
3 \cdot 6 \\
8 \cdot 4\end{array}$ & $\begin{array}{r}1 \cdot 3 \\
94 \cdot 0 \\
3 \cdot 5 \\
1 \cdot 2\end{array}$ & $\begin{array}{r}23 \cdot 0 \\
61 \cdot 5 \\
0 \cdot 0 \\
15 \cdot 5\end{array}$ & $\begin{array}{r}8 \cdot 5 \\
65 \cdot 0 \\
0 \cdot 0 \\
26 \cdot 5\end{array}$ \\
\hline All venereal diseases & $100 \cdot 0$ & $100 \cdot 0$ & $100 \cdot 0$ & $100 \cdot 0$ & $100 \cdot 0$ & $100 \cdot 0$ & $100 \cdot 0$ & $100 \cdot 0$ \\
\hline 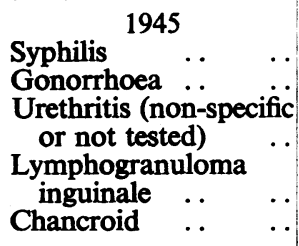 & $\begin{array}{r}6 \cdot 4 \\
46 \cdot 8 \\
24 \cdot 6 \\
4 \cdot 7 \\
17 \cdot 5\end{array}$ & $\begin{array}{r}1.9 \\
29.9 \\
51.6 \\
8 \cdot 8 \\
7 \cdot 8\end{array}$ & $\begin{array}{r}2 \cdot 7 \\
58 \cdot 3 \\
35 \cdot 8 \\
\\
1 \cdot 1 \\
2 \cdot 1\end{array}$ & $\begin{array}{r}5 \cdot 8 \\
24 \cdot 9 \\
54 \cdot 6 \\
8 \cdot 3 \\
6 \cdot 3\end{array}$ & $\begin{array}{r}21 \cdot 1 \\
47 \cdot 7 \\
14 \cdot 7 \\
2 \cdot 8 \\
13 \cdot 8\end{array}$ & $\begin{array}{r}41 \cdot 7 \\
8 \cdot 1 \\
6 \cdot 2\end{array}$ & $\begin{array}{r}25 \cdot 0 \\
0 \cdot 0 \\
18 \cdot 8\end{array}$ & $\begin{array}{r}57 \cdot 0 \\
8 \cdot 0 \\
10 \cdot 5\end{array}$ \\
\hline All venereal diseases & $100 \cdot 0$ & $100 \cdot 0$ & $100 \cdot 0$ & $100 \cdot 0$ & $100 \cdot 0$ & $100 \cdot 0$ & $100 \cdot 0$ & $100 \cdot 0$ \\
\hline
\end{tabular}

earlier years, 1945 figures for gonorrhoea refer only to G-C positive cases reported as such.

(b) Due consideration to the difference between the total venereal disease rates shown in Table VI is a necessary prerequisite to just comparison between the actual prevalence of any one disease among the two categories of personnel. The figures for Africans in Table VII are therefore comparable to those for U.K. troops only if multiplied by the factors shown below:

$\begin{array}{ccccccc} & & & \text { Gold Coast } & \text { Nigeria } & \text { Sierra Leone } & \text { Gambia } \\ 1944 & \ldots & \ldots & 6 \cdot 1 & 4 \cdot 3 & 6 \cdot 1 & 5.4 \\ 1945 & \ldots & \ldots & 5.9 & 6.3 & 3.7 & 15.0\end{array}$

Thus the actual syphilis rate among U.K. troops was lower than that of Africans in both years in three of the four territories. In Sierra Leone, where syphilis was more prevalent among U.K. troops than among Africans, the ratio of the two rates was $18 \cdot 0: 8 \cdot 2$ (1944) and $21 \cdot 1: 11 \cdot 1$ (1945). The most consistent feature of Table VII is the low proportion of G-C positive cases reported as such among Africans with urethritis, but this does not necessarily signify a higher proportionate incidence of a non-specific type. Cases not reported as G-C positive include cases untested, possibly owing to pressure of work in African units where the venereal disease rate was in fact exceptionally high. For the whole command the total venereal disease rate among Africans reached the alarming figure of $48 \%$ in 1945 , being then six times as high as the total venereal disease rate for U.K. troops.

In the Gambia the rate among African troops during that year was over $60 \%$. With due regard to the rate of recruitment, to the period of service, and to allocation for service in other theatres, figures such as these force us to infer that a very 
substantial proportion of cases reported in a given year must refer to successive infections of the same individuals. Notwithstanding, it is difficult to believe that a considerable proportion of Africans are free from infection at enlistment and remain so throughout their period of service. On the other hand, it would be unjust to Army hygiene authorities to attribute the almost universal prevalence of venereal disease among African troops to conditions of service. Comparison between experience of Africans in their native habitat and Africans serving in other theatres, especially in South East Asia (vide infra), suggests the reverse. It is reasonable to surmise that low estimates of the prevalence of venereal disease among civilians in British West Africa reflect defective provision of medical man-power by our colonial authorities. A recent article in the Lancet (May 17, 1947) citing Willcox (1946) dispels any illusions which published statistics concerning the civilian populations (e.g. a venereal disease rate of $0.8 \%$ in the Gambia, 1943) might encourage us to entertain. It suffices to quote one sentence from this article: "The colonial medical service is hopelessly understaffed for the job-in Nigeria, for example, there is only one doctor per 130,000 of population." Against this, we have to weigh the fact that there was (1945) one doctor to every 428 soldiers under British command.

For each personnel category Table VIII shows which diseases individually make a conspicuous contribution to certifications of troops as unfit for further service in the theatre during the last three years of the quinquennium. The considerable

TABLE VIII

Percentages of Total Evacuations (U.K. Troops) Or Invalidings (Afr.): West Africa

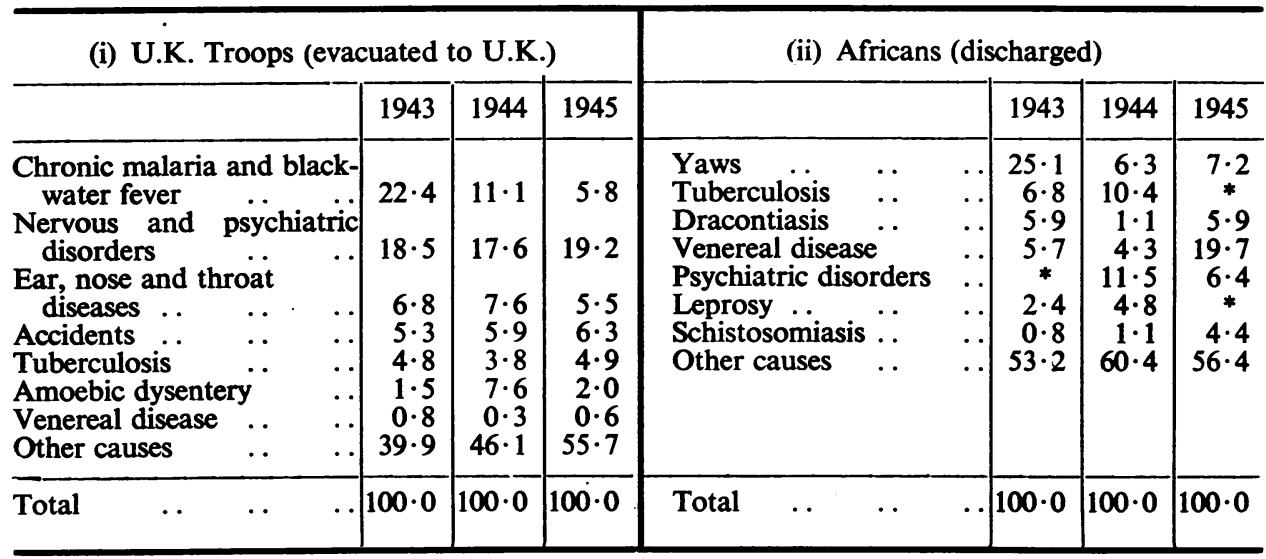

* Figures not available.

contribution of other causes to invalidings or evacuations in this table does not signify that any specific disease other than those listed above makes a considerable contribution to the total. It is made up of the contribution of a large number of conditions whose individual contributions to the total are trivial. Mutatis mutandis 

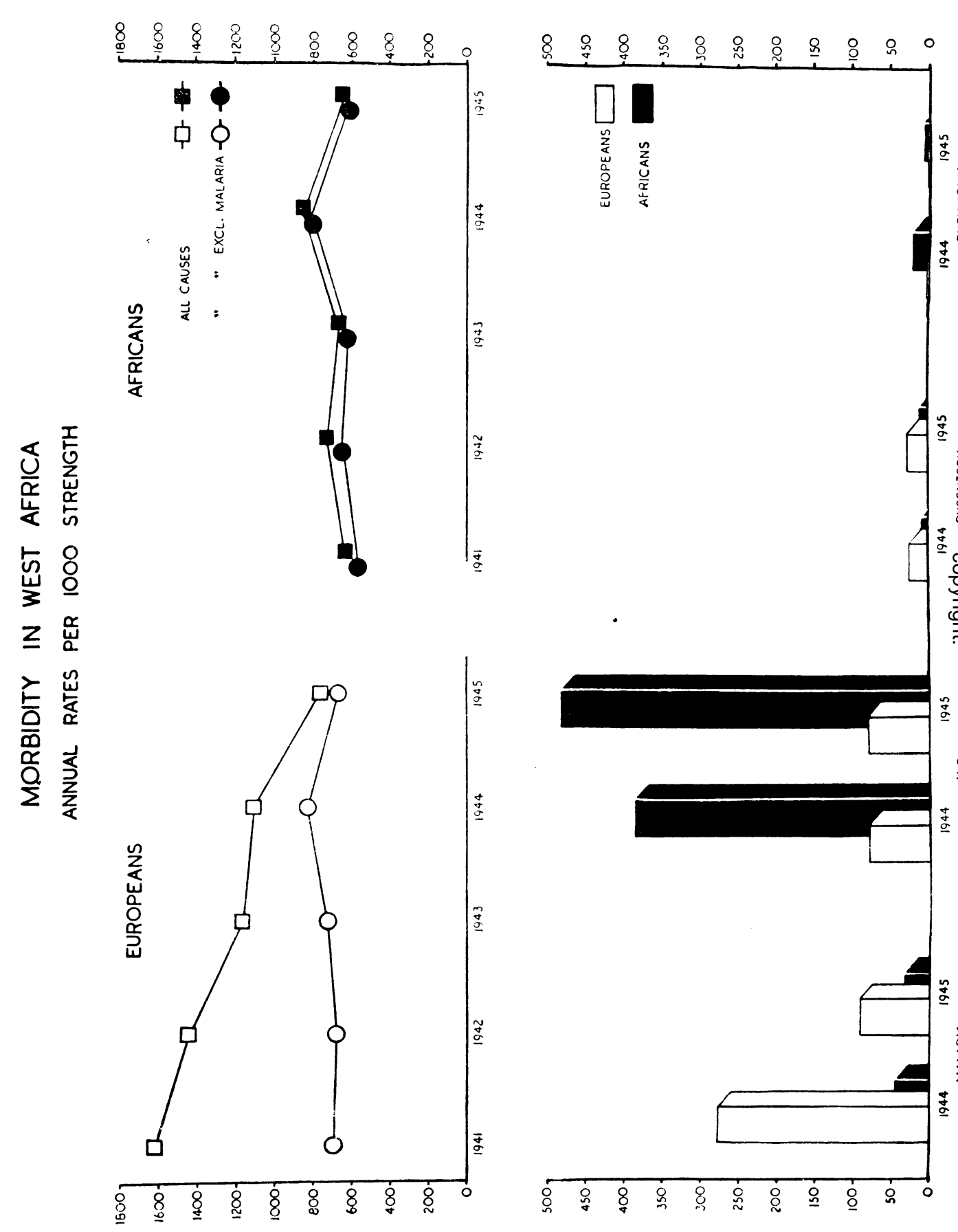

w
$c$
c
0
0
$\frac{1}{1}$
$\stackrel{0}{0}$

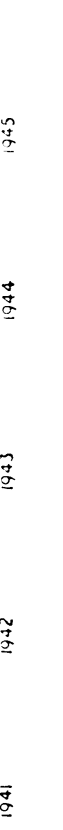


MEDICAL ETHNOGRAPHY OF THE SECOND WORLD WAR 261

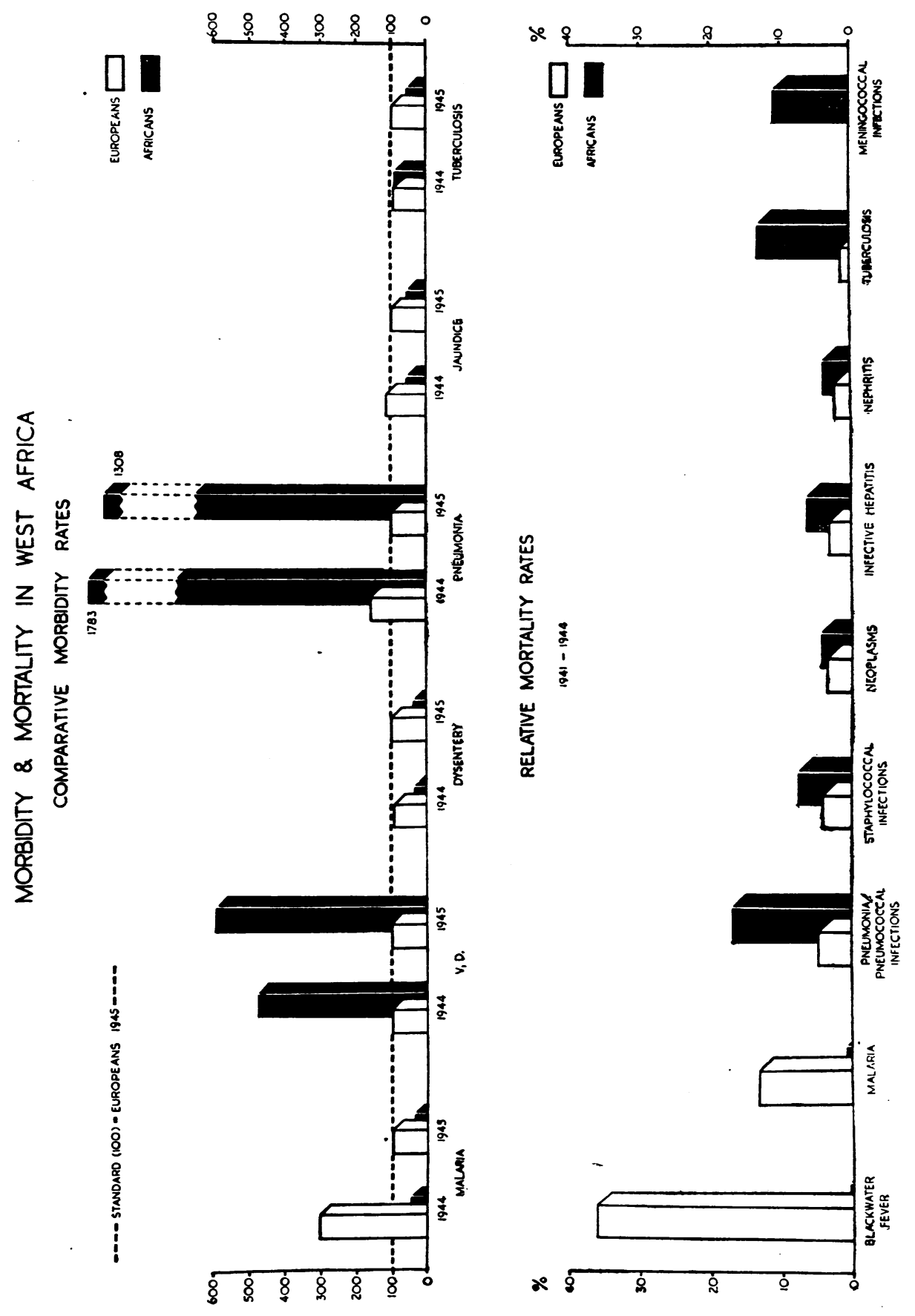


the same remarks apply to Table XIII. It is noteworthy that four tropical conditions (yaws, dracontiasis, schistosomiasis, and leprosy), which collectively made a negligible contribution to the total figures for U.K. troops, account for a considerable proportion (17\% in 1945 and $35 \%$ in 1943) of invalidings among Africans. The sequelae of malaria, including blackwater fever, were a major source of wastage among British troops but of negligible importance among Africans. The same is true of deaths (Table IX). The other most notable feature of Table IX is the relatively high contribution of tuberculosis, pneumococcal, and meningococcal infections to deaths among Africans.

TABLE IX

Rrlative Mortality Rates: West Africa

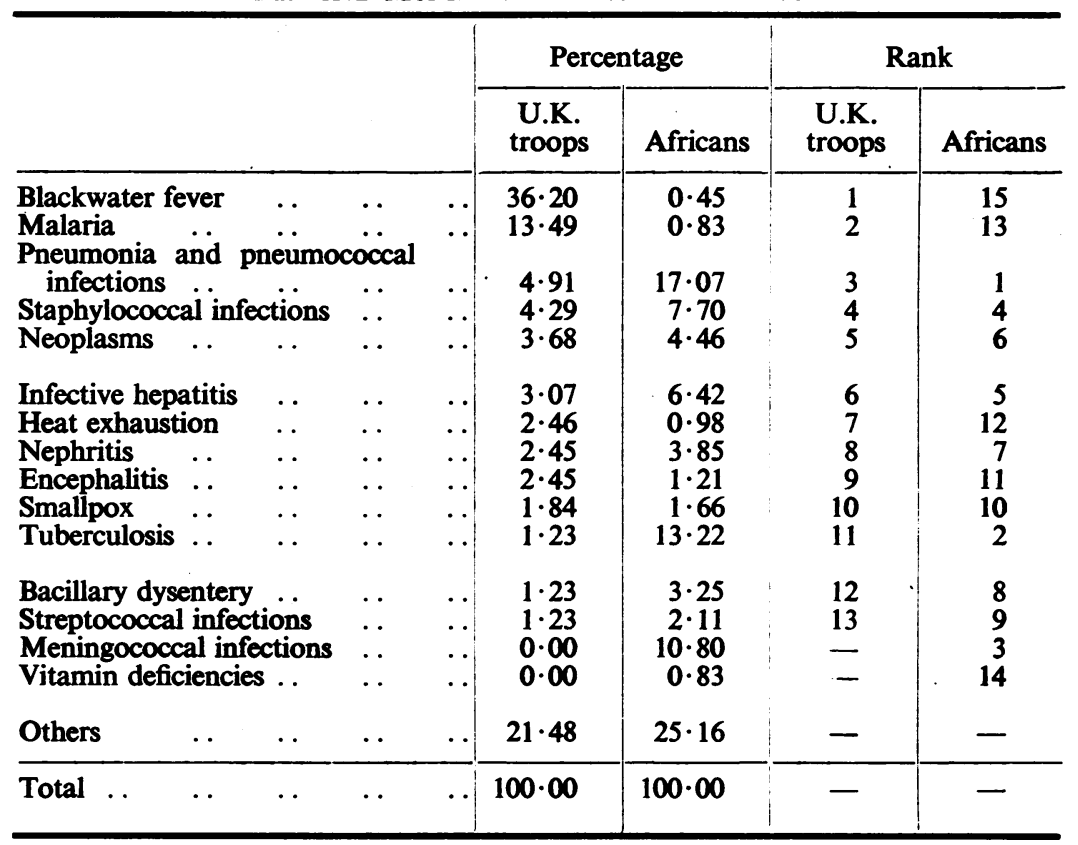

\section{The Middle East Theatre}

For the Middle East Theatre we have separate statistics referable to three consecutive years with respect to three categories of personnel, viz. U.K. troops, Indian regiments, and Africans, as specified in Section 2 above. Within each personnel category the relative contributions of the major hospitalized diseases were as shown in Table $X$. The local risk was subject to wide variation in the several commands (Egypt, Cyrenaica and Tripolitania, Palestine, Sudan and Eritrea, Cyprus, Syria, Malta, Aden). Fortunately, it was possible to adjust the figures accordingly, as shown in Table XI, which cites the corresponding relative morbidity rates standardized with respect to locality. This Table exhibits what proved to be more or less important sources of wastage for each type of personnel. 
TABLE X

Crude Relative Morbidity Rates: Middle East

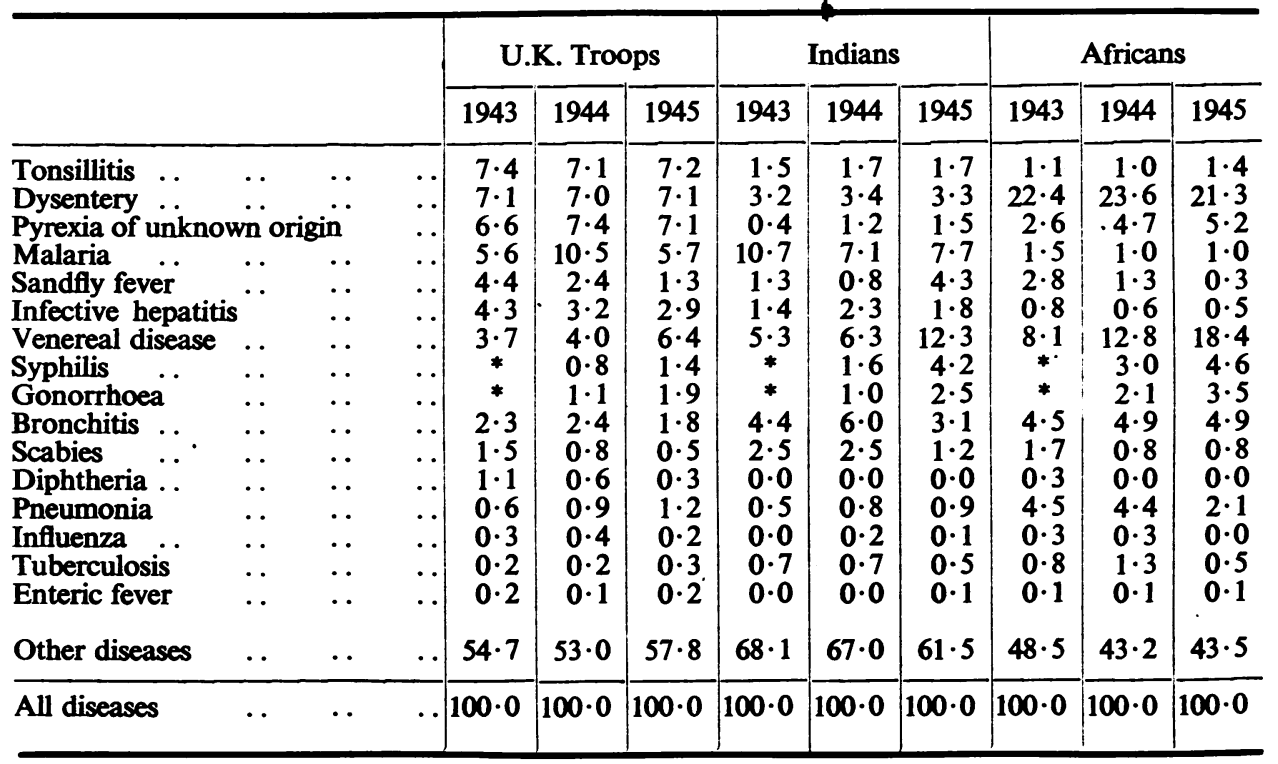

* Figures not available.

TABLE XI

Locality-Standardized Relative Morbidity Rates: Middle East

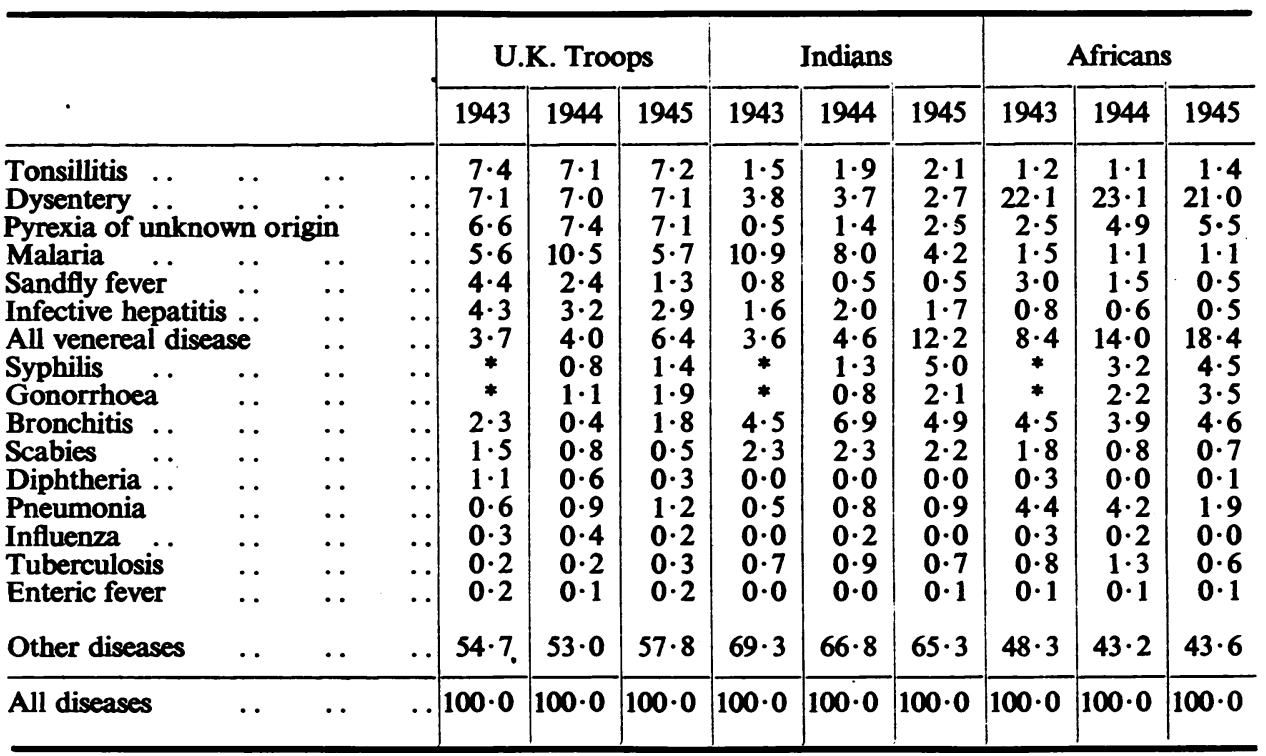

* Figures not available. 
TABLE XII

Comparattve-Localtry-Standardized Morbidity Rates: Middle East

\begin{tabular}{|c|c|c|c|c|c|c|c|c|c|}
\hline & & & \multirow{2}{*}{$\begin{array}{c}\text { U.K. Troops } \\
1943-45\end{array}$} & \multicolumn{3}{|c|}{ Indians } & \multicolumn{3}{|c|}{ Africans } \\
\hline & & & & 1943 & 1944 & 1945 & 1943 & 1944 & 1945 \\
\hline $\begin{array}{l}\text { Tonsillitis } \\
\text { Influenza } \\
\text { Pneumonia } \\
\text { Tuberculosis } \\
\text { Bronchitis }\end{array}$ & $\begin{array}{l}\cdots \\
\cdots \\
\cdots \\
\cdots \\
\cdots\end{array}$ & $\begin{array}{l}. \\
. \\
. \\
. \\
.\end{array}$ & $\begin{array}{l}100 \cdot 0 \\
100 \cdot 0 \\
100 \cdot 0 \\
100 \cdot 0 \\
100 \cdot 0\end{array}$ & $\begin{array}{r}17 \cdot 9 \\
6 \cdot 2 \\
63 \cdot 2 \\
266 \cdot 7 \\
160 \cdot 3\end{array}$ & $\begin{array}{r}27 \cdot 8 \\
56 \cdot 4 \\
92 \cdot 5 \\
450 \cdot 0 \\
293 \cdot 8\end{array}$ & $\begin{array}{r}23 \cdot 4 \\
5 \cdot 3 \\
62 \cdot 6 \\
205 \cdot 0 \\
218 \cdot 9\end{array}$ & $\begin{array}{r}17 \cdot 2 \\
109 \cdot 8 \\
773 \cdot 3 \\
445 \cdot 9 \\
222 \cdot 3\end{array}$ & $\begin{array}{r}19 \cdot 6 \\
77 \cdot 1 \\
605 \cdot 5 \\
841 \cdot 0 \\
217 \cdot 3\end{array}$ & $\begin{array}{r}20 \cdot 6 \\
17 \cdot 3 \\
173 \cdot 2 \\
241 \cdot 6 \\
280 \cdot 2\end{array}$ \\
\hline $\begin{array}{l}\text { All venereal dise } \\
\text { Syphilis ... } \\
\text { Gonorrhoea } \\
\text { Scabies .. }\end{array}$ & $\begin{array}{l}\text { ease } \\
. \\
\ldots \\
\ldots\end{array}$ & $\begin{array}{l}\cdots \\
\cdots \\
\cdots \\
.\end{array}$ & $\begin{array}{l}100 \cdot 0 \\
100 \cdot 0 \\
100 \cdot 0 \\
100 \cdot 0\end{array}$ & $\begin{array}{c}79 \cdot 1 \\
* \\
* \\
153 \cdot 1\end{array}$ & $\begin{array}{r}116 \cdot 8 \\
180 \cdot 7 \\
75 \cdot 1 \\
308 \cdot 7\end{array}$ & $\begin{array}{r}154 \cdot 5 \\
287 \cdot 8 \\
90 \cdot 9 \\
371 \cdot 0\end{array}$ & $\begin{array}{c}253 \cdot 3 \\
* \\
* \\
129 \cdot 6\end{array}$ & $\begin{array}{l}459 \cdot 6 \\
545 \cdot 3 \\
265 \cdot 0 \\
131 \cdot 2\end{array}$ & $\begin{array}{l}314 \cdot 0 \\
349 \cdot 4 \\
200 \cdot 4 \\
161 \cdot 5\end{array}$ \\
\hline $\begin{array}{l}\text { Diphtheria } \\
\text { Mumps .. } \\
\text { Measles .. } \\
\text { Rheumatic fever } \\
\text { Meningococcal }\end{array}$ & $\begin{array}{l}\cdots \\
\cdots \\
\cdots \\
\text { infectio }\end{array}$ & $\begin{array}{l}. \\
\cdots \\
\cdots \\
\text { on }\end{array}$ & $\begin{array}{l}100 \cdot 0 \\
100 \cdot 0 \\
100 \cdot 0 \\
100 \cdot 0 \\
100 \cdot 0\end{array}$ & $\begin{array}{r}1 \cdot 9 \\
308 \cdot 2 \\
15 \cdot 7 \\
33 \cdot 7 \\
56 \cdot 3\end{array}$ & $\begin{array}{r}2 \cdot 6 \\
4,152 \cdot 4 \\
93 \cdot 5 \\
83 \cdot 9 \\
75 \cdot 0\end{array}$ & $\begin{array}{r}1 \cdot 8 \\
645 \cdot 0 \\
63 \cdot 6 \\
40 \cdot 0 \\
2 \cdot 7\end{array}$ & $\begin{array}{r}33 \cdot 5 \\
2,285 \cdot 3 \\
292 \cdot 3 \\
80 \cdot 2 \\
1,253 \cdot 0\end{array}$ & $\begin{array}{r}3 \cdot 0 \\
2,219 \cdot 0 \\
9 \cdot 7 \\
87 \cdot 1 \\
650 \cdot 0\end{array}$ & $\begin{array}{r}19 \cdot 1 \\
312 \cdot 5 \\
22 \cdot 7 \\
33 \cdot 3 \\
490 \cdot 9\end{array}$ \\
\hline $\begin{array}{l}\text { Malaria .. } \\
\text { Dysentery } \\
\text { Infective hepatit } \\
\text { Sandfly fever } \\
\text { Pyrexia'of unkno } \\
\text { Enteric fever } \\
\text { Smallpox } \\
\text { Typhus . } \\
\text { Relapsing fever }\end{array}$ & $\begin{array}{l}\ldots \\
\text { tis } \\
\ldots \\
\text { ownorig } \\
\ldots \\
\ldots \\
\ldots \\
. .\end{array}$ & $\begin{array}{c}\cdots \\
\cdots \\
\cdots \\
\ddot{g i n} \\
\cdots \\
\cdots \\
\cdots \\
\cdots\end{array}$ & $\begin{array}{l}100 \cdot 0 \\
100 \cdot 0 \\
100 \cdot 0 \\
100 \cdot 0 \\
100 \cdot 0 \\
100 \cdot 0 \\
100 \cdot 0 \\
100 \cdot 0 \\
100 \cdot 0\end{array}$ & $\begin{array}{r}157 \cdot 6 \\
43 \cdot 7 \\
29 \cdot 8 \\
14 \cdot 2 \\
7 \cdot 0 \\
9 \cdot 2 \\
50 \cdot 4 \\
84 \cdot 3 \\
273 \cdot 4\end{array}$ & $\begin{array}{r}77 \cdot 3 \\
54 \cdot 0 \\
64 \cdot 0 \\
19 \cdot 5 \\
19 \cdot 0 \\
90 \cdot 9 \\
162 \cdot 2 \\
0 \cdot 0 \\
275 \cdot 0\end{array}$ & $\begin{array}{r}59 \cdot 5 \\
31 \cdot 2 \\
47 \cdot 7 \\
29 \cdot 4 \\
28 \cdot 5 \\
28 \cdot 4 \\
7 \cdot 5 \\
10 \cdot 0 \\
216 \cdot 7\end{array}$ & $\begin{array}{r}29 \cdot 4 \\
350 \cdot 3 \\
20 \cdot 4 \\
73 \cdot 7 \\
42 \cdot 0 \\
87 \cdot 1 \\
141 \cdot 7 \\
62 \cdot 6 \\
37 \cdot 4\end{array}$ & $\begin{array}{r}13 \cdot 3 \\
430 \cdot 6 \\
26 \cdot 0 \\
82.5 \\
87 \cdot 3 \\
63 \cdot 6 \\
111 \cdot 1 \\
125 \cdot 0 \\
0.0\end{array}$ & $\begin{array}{r}20 \cdot 2 \\
322 \cdot 7 \\
18 \cdot 4 \\
39 \cdot 8 \\
83 \cdot 7 \\
38 \cdot 3 \\
450 \cdot 0 \\
100 \cdot 0 \\
300 \cdot 0\end{array}$ \\
\hline
\end{tabular}

* Figures not available.

Table XII exhibits the differential incidence of the same diseases. In this Table, the figure for U.K. troops during the corresponding year is for each disease the standard of comparison. The outstanding conclusions which emerge from Table XII are as follows:

(i) U.K. troops were much more prone than either Indians or Africans to: tonsillar infections diphtheria

rheumatic fever infective hepatitis sandfly fever the enteric group of fevers

(ii) U.K. troops were much less prone than either Indians or Africans to: tuberculosis bronchitis mumps

(iii) Indian troops were more prone to relapsing fever than either U.K. troops or Africans.

(iv) Indian troops were less prone than either U.K. troops or Africans to: pneumonia meningococcal infections dysentery typhus 
(v) Africans were more prone than either Indians or U.K. troops to: pneumonia

venereal disease of all types

dysentery

(vi) Africans were less prone than either Indians or U.K. troops to malaria.

TABLE XIII

Relative Mortality Rates: Middle EAst

\begin{tabular}{|c|c|c|c|c|c|c|c|c|c|c|c|c|}
\hline & \multicolumn{3}{|c|}{ U.K. Troops } & \multicolumn{3}{|c|}{ Indians } & \multicolumn{3}{|c|}{ Africans } \\
\hline & & & & 1943 & 1944 & 1945 & 1943 & 1944 & 1945 & 1943 & 1944 & 1945 \\
\hline $\begin{array}{l}\text { Injuries ... } \\
\text { Enteric fever } \\
\text { Tuberculosis } \\
\text { Pneumonia } \\
\text { Smallpox ... } \\
\text { Malaria } \\
\text { Infective hepa } \\
\text { Meningococca } \\
\text { Dysentery .. } \\
\text { Other causes }\end{array}$ & $\begin{array}{l}. \\
. \\
. \\
. \\
\because \\
\ldots \\
\ldots \\
\text { fection } \\
. \\
.\end{array}$ & $\begin{array}{l}. \\
. \\
. \\
\cdots \\
\cdots \\
. . \\
. \\
.\end{array}$ & \begin{tabular}{l|}
. \\
. \\
.. \\
. \\
. \\
.. \\
. \\
.. \\
..
\end{tabular} & $\begin{array}{r}47.9 \\
4.3 \\
2.6 \\
2.5 \\
2.2 \\
1.3 \\
1.1 \\
0.8 \\
0.8 \\
36.5\end{array}$ & $\begin{array}{r}41 \cdot 0 \\
3.6 \\
3.3 \\
4.4 \\
1.8 \\
1 \cdot 1 \\
3 \cdot 3 \\
2.2 \\
0.4 \\
38.9\end{array}$ & $\begin{array}{r}41.9 \\
5.8 \\
1.9 \\
1.9 \\
0.0 \\
1.3 \\
0.7 \\
1.3 \\
1.3 \\
43.9\end{array}$ & $\begin{array}{r}38.2 \\
0.6 \\
26.1 \\
2.4 \\
0.0 \\
0.6 \\
1.2 \\
0.6 \\
0.0 \\
30.3\end{array}$ & $\begin{array}{r}30.5 \\
0.0 \\
37.5 \\
1.6 \\
0.0 \\
1.6 \\
2.3 \\
0.8 \\
0.0 \\
25.7\end{array}$ & $\begin{array}{r}38 \cdot 0 \\
0.6 \\
30.7 \\
1 \cdot 8 \\
0.0 \\
0 \cdot 6 \\
3 \cdot 0 \\
0 \cdot 0 \\
0.0 \\
25 \cdot 3\end{array}$ & $\begin{array}{r}12 \cdot 2 \\
4 \cdot 5 \\
20 \cdot 2 \\
11 \cdot 2 \\
1.4 \\
0.9 \\
0.9 \\
4 \cdot 0 \\
0.9 \\
43 \cdot 8\end{array}$ & $\begin{array}{r}11.8 \\
1.6 \\
30.6 \\
5.1 \\
2.8 \\
0.4 \\
0.8 \\
2.8 \\
0.6 \\
43.5\end{array}$ & $\begin{array}{r}9.7 \\
0.9 \\
30.0 \\
2.8 \\
0.5 \\
0.5 \\
1.4 \\
4.2 \\
1.8 \\
48.2\end{array}$ \\
\hline All deaths & .. & . & . & $100 \cdot 0$ & $100.0^{\circ}$ & $100 \cdot 0$ & 100.0 & $100 \cdot 0$ & $100 \cdot 0$ & $100 \cdot 0$ & $100 \cdot 0$ & $100 \cdot 0$ \\
\hline
\end{tabular}

TABLE XIV

Fatality Rates Per Hundred Cases: Middle East

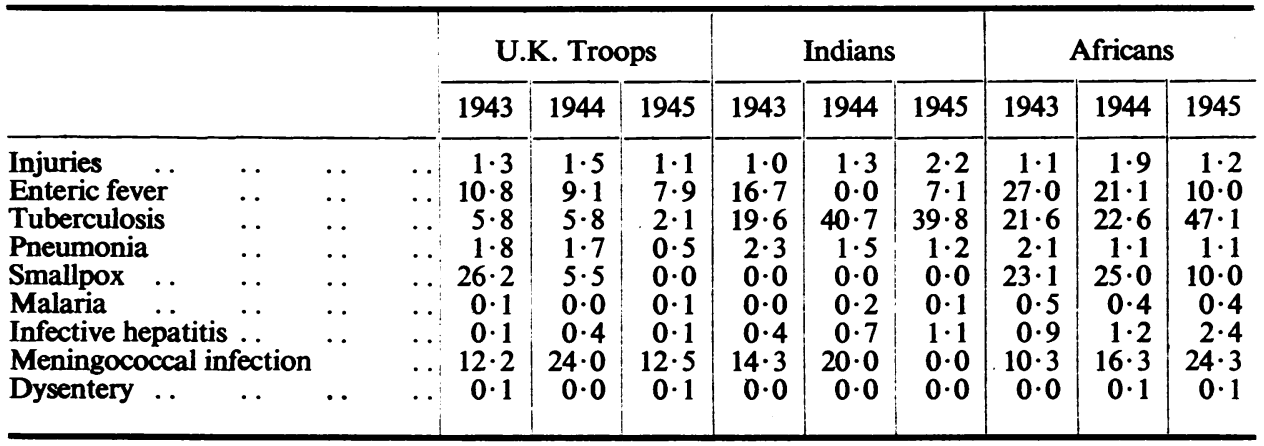

TABLE XV

Comparative Mortality and Fataltiy Rates: Middle East

\begin{tabular}{|c|c|c|c|c|c|c|c|c|}
\hline & & \multirow{2}{*}{$\begin{array}{c}\text { U.K. Troops } \\
1943-1945\end{array}$} & \multicolumn{3}{|c|}{ Indians } & \multicolumn{3}{|c|}{ Africans } \\
\hline & & & 1943 & 1944 & 1945 & 1943 & 1944 & 1945 \\
\hline (i) $\begin{array}{c}\text { Mortality } \\
\text { Injuries } \\
\text { Tuberculosis } \\
\text { Pneumonia }\end{array}$ & \begin{tabular}{l|}
$\cdots$ \\
$\cdots$ \\
$\cdots$
\end{tabular} & $\begin{array}{l}100 \cdot 0 \\
100 \cdot 0 \\
100 \cdot 0\end{array}$ & $\begin{array}{r}78 \cdot 9 \\
1,020 \cdot 0 \\
95 \cdot 9\end{array}$ & $\begin{array}{r}165 \cdot 1 \\
2,550 \cdot 9 \\
79 \cdot 7\end{array}$ & $\begin{array}{r}149 \cdot 0 \\
2,614 \cdot 0 \\
153 \cdot 8\end{array}$ & $\begin{array}{r}49 \cdot 5 \\
1,620 \cdot 0 \\
918 \cdot 4\end{array}$ & $\begin{array}{r}96 \cdot 6 \\
3,153 \cdot 1 \\
394 \cdot 3\end{array}$ & $\begin{array}{r}71 \cdot 9 \\
4,822 \cdot 4 \\
445 \cdot 2\end{array}$ \\
\hline 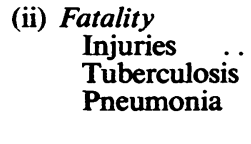 & $\begin{array}{l}\cdots \\
\cdots \\
\cdots\end{array}$ & $\begin{array}{l}100 \cdot 0 \\
100 \cdot 0 \\
100 \cdot 0\end{array}$ & $\begin{array}{r}76 \cdot 9 \\
337 \cdot 0 \\
132 \cdot 0\end{array}$ & $\begin{array}{r}91 \cdot 2 \\
705 \cdot 0 \\
88 \cdot 6\end{array}$ & $\begin{array}{r}199 \cdot 1 \\
1,897 \cdot 1 \\
261 \cdot 7\end{array}$ & $\begin{array}{r}84 \cdot 6 \\
374 \cdot 0 \\
118 \cdot 0\end{array}$ & $\begin{array}{r}128 \cdot 6 \\
391 \cdot 9 \\
65 \cdot 1\end{array}$ & $\begin{array}{r}109 \cdot 8 \\
2,242 \cdot 9 \\
225 \cdot 5\end{array}$ \\
\hline
\end{tabular}




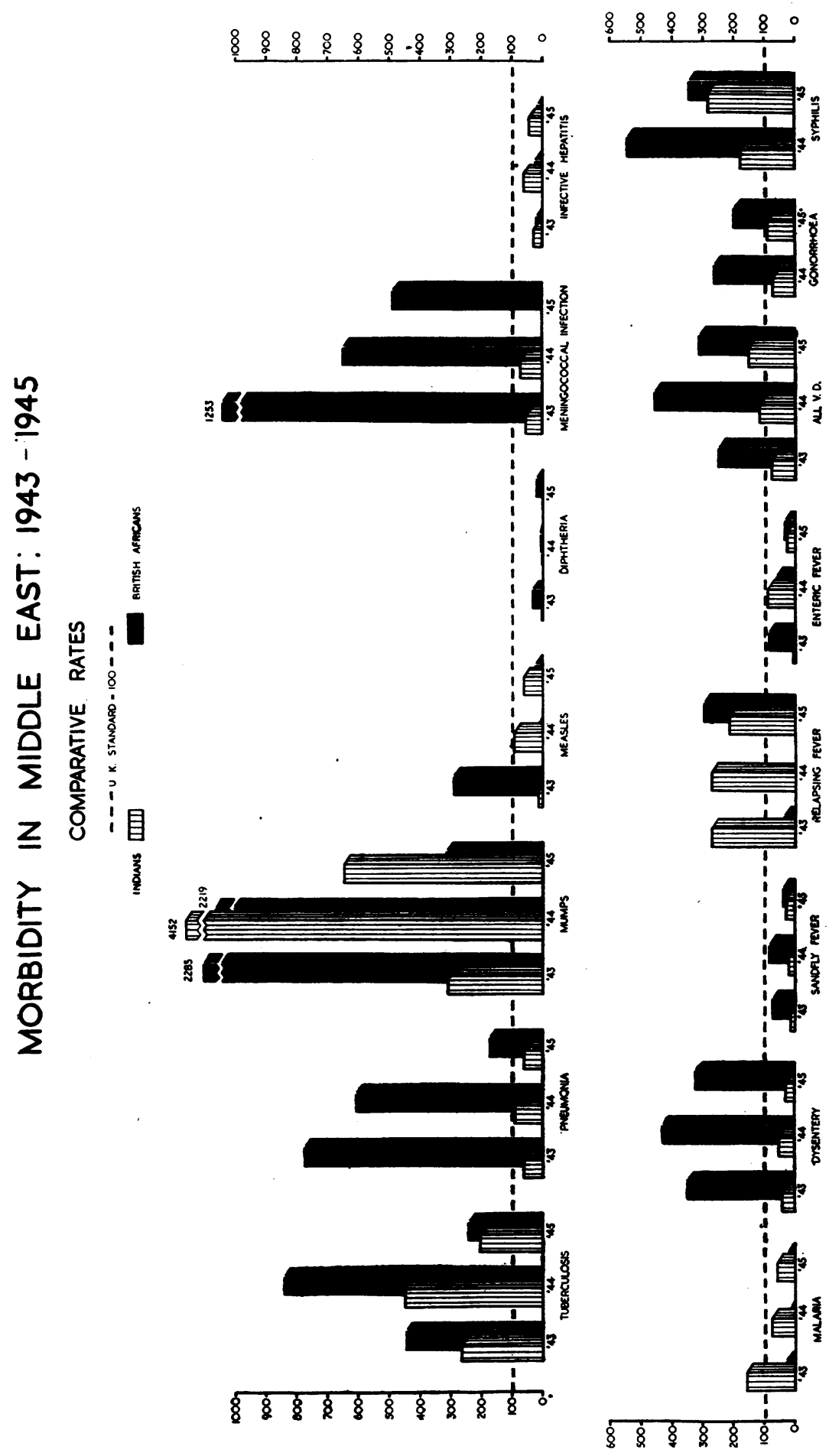


MEDICAL ETHNOGRAPHY OF THE SECOND WORLD WAR 267

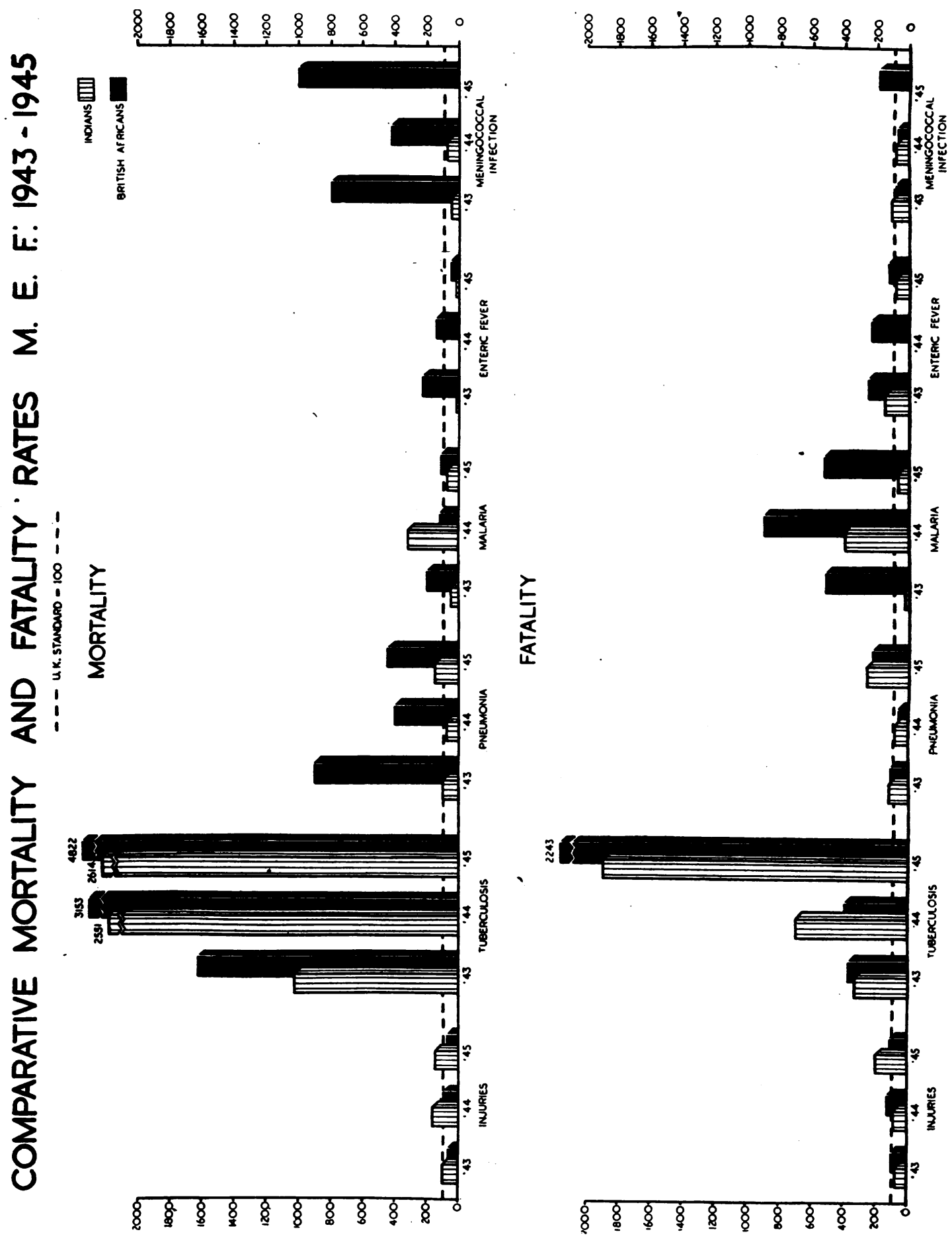


Fatality rates, as shown in Table XIV, calculated for most diseases would be unreliable owing to the relatively low mortality in the theatre. The one striking feature of data with respect to mortality and fatality summarized in Tables XIII-XV is en rapport with current teaching, viz. the exceptionally high fatality of tuberculosis among Indian and African, in contradistinction to U.K., troops.

\section{ITALY AND SiCILY}

Available data for this theatre refer to all medical units including, besides cases treated in hospital, cases treated in field ambulances and other forward units. It has not been possible to apply to the data the method of standardization employed in the foregoing sections. With due regard to this caveat and to differences with respect to the composition of African personnel, as stated in Section 2, experience in this theatre tallies with that of the Middle East in so far as:

TABLE XVI

Relative Morbidity Rates (all Medical Units) 1944: Central Mediterranean

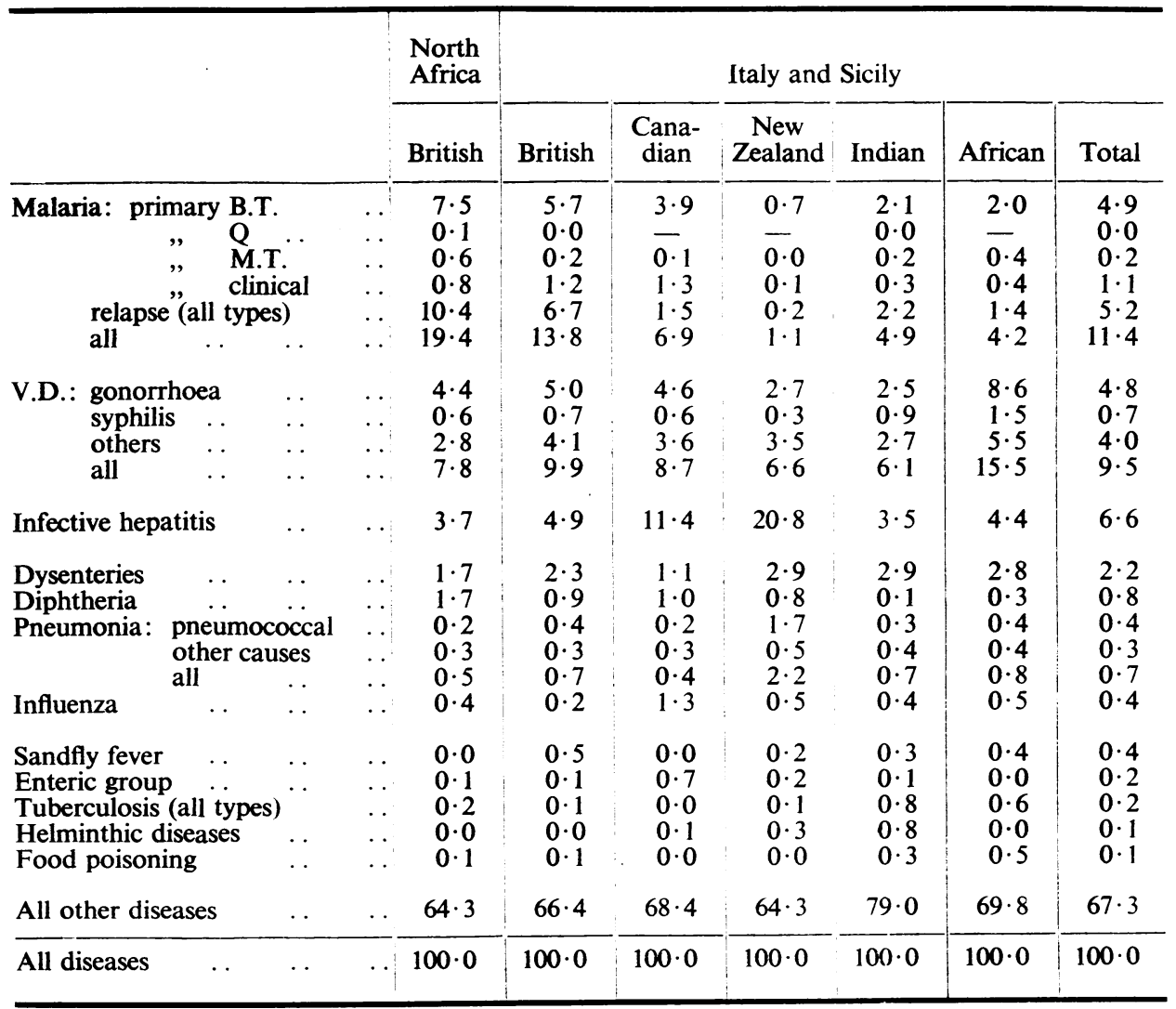


MEDICAL ETHNOGRAPHY OF THE SECOND WORLD WAR 269

(i) African troops were less prone to malaria and more prone to venereal diseases than either Indians or troops of European stock;

(ii) Both Indians and Africans were less prone than U.K. troops to sandfly fever, to the enteric group of fevers, and to diphtheria;

(iii) Both Africans and Indians were more prone to tuberculosis.

TABLE XVII

Comparative Morbidity Rates (all Medical Untrs) 1944: Central Mediterranean

\begin{tabular}{|c|c|c|c|c|c|c|c|c|c|}
\hline & & & \multirow{2}{*}{$\begin{array}{l}\text { North } \\
\text { Africa }\end{array}$} & \multicolumn{6}{|c|}{ Italy and Sicily } \\
\hline & & & & British & $\begin{array}{c}\text { Cana- } \\
\text { dian }\end{array}$ & $\begin{array}{c}\text { New } \\
\text { Zealand }\end{array}$ & Indian & African & Total \\
\hline $\begin{array}{cc}\text { Malaria: } & \text { primary B.T } \\
& = \\
& \mathbf{Q} \\
\text { relapse" (all type } & \text { clin } \\
\text { all } & . .\end{array}$ & $\begin{array}{l}\text { r. } \\
\text { ical } \\
\text { s) }\end{array}$ & \begin{tabular}{l|}
$\cdots$ \\
$\cdots$ \\
$\cdots$ \\
$\cdots$ \\
$\cdots$
\end{tabular} & $\begin{array}{r}97 \\
686 \\
163 \\
46 \\
113 \\
102\end{array}$ & $\begin{array}{l}100 \\
100 \\
100 \\
100 \\
100 \\
100\end{array}$ & $\begin{array}{r}106 \\
80 \\
162 \\
35 \\
76\end{array}$ & $\begin{array}{r}20 \\
4 \\
16 \\
6 \\
12\end{array}$ & $\begin{array}{l}30 \\
75 \\
22 \\
28 \\
29\end{array}$ & $\begin{array}{r}39 \\
29 \\
156 \\
39 \\
23 \\
33\end{array}$ & $\begin{array}{l}92 \\
71 \\
94 \\
97 \\
83 \\
88\end{array}$ \\
\hline $\begin{array}{ll}\text { V.D.: } & \begin{array}{l}\text { gonorrhoea } \\
\text { syphilis }\end{array} \\
\begin{array}{l}\text { others } \\
\text { all }\end{array} & \ldots \\
& \ldots\end{array}$ & $\begin{array}{l}. \\
\therefore \\
\therefore\end{array}$ & \begin{tabular}{l|}
$\cdots$ \\
$\cdots$ \\
$\cdots$ \\
$\cdots$
\end{tabular} & $\begin{array}{l}64 \\
58 \\
50 \\
58\end{array}$ & $\begin{array}{l}100 \\
100 \\
100 \\
100\end{array}$ & $\begin{array}{l}140 \\
123 \\
132 \\
136\end{array}$ & $\begin{array}{r}88 \\
75 \\
136 \\
107\end{array}$ & $\begin{array}{r}42 \\
104 \\
54 \\
52\end{array}$ & $\begin{array}{l}188 \\
224 \\
145 \\
172\end{array}$ & $\begin{array}{l}102 \\
105 \\
102 \\
102\end{array}$ \\
\hline Infective hepatitis & .. & .. & 54 & 100 & 353 & 677 & 59 & 98 & 142 \\
\hline $\begin{array}{lc}\begin{array}{l}\text { Dysenteries } \\
\text { Diphtheria } \\
\text { Pneumonia: }\end{array} & \ldots \\
& \begin{array}{l}\text { pneumoc } \\
\text { other cal } \\
\text { all }\end{array} \\
\text { Influenza } & \ldots\end{array}$ & $\begin{array}{l}\ldots \\
\ldots \\
\text { occal } \\
\text { uses } \\
\ldots \\
\ldots\end{array}$ & \begin{tabular}{l|}
$\cdots$ \\
$\cdots$ \\
$\cdots$ \\
$\cdots$ \\
$\cdots$
\end{tabular} & $\begin{array}{r}54 \\
140 \\
38 \\
63 \\
51 \\
124\end{array}$ & $\begin{array}{l}100 \\
100 \\
100 \\
100 \\
100 \\
100\end{array}$ & $\begin{array}{r}76 \\
163 \\
85 \\
116 \\
100 \\
967\end{array}$ & $\begin{array}{l}202 \\
135 \\
776 \\
256 \\
526 \\
354\end{array}$ & $\begin{array}{r}106 \\
6 \\
82 \\
90 \\
86 \\
148\end{array}$ & $\begin{array}{r}134 \\
34 \\
133 \\
116 \\
125 \\
235\end{array}$ & $\begin{array}{l}102 \\
100 \\
119 \\
106 \\
113 \\
204\end{array}$ \\
\hline $\begin{array}{l}\text { Sandfly fever } \\
\text { Enteric group } \ldots \\
\text { Tuberculosis (all types } \\
\text { Helminthic diseases } \\
\text { Food poisoning }\end{array}$ & $\begin{array}{l}\cdots \\
\cdots \\
\cdots \\
\therefore\end{array}$ & $\begin{array}{l}\cdots \\
\cdots \\
\cdots \\
\cdots \\
.\end{array}$ & $\begin{array}{r}1 \\
38 \\
110 \\
76 \\
96\end{array}$ & $\begin{array}{l}100 \\
100 \\
100 \\
100 \\
100\end{array}$ & $\begin{array}{r}13 \\
791 \\
48 \\
238 \\
70\end{array}$ & $\begin{array}{r}68 \\
256 \\
73 \\
1,329 \\
30\end{array}$ & $\begin{array}{r}46 \\
32 \\
589 \\
1,757 \\
230\end{array}$ & $\begin{array}{r}94 \\
38 \\
560 \\
33 \\
626\end{array}$ & $\begin{array}{r}86 \\
170 \\
138 \\
267 \\
116\end{array}$ \\
\hline All other diseases & . & .. & 71 & 100 & 158 & 157 & 99 & 116 & 108 \\
\hline All diseases & .. & & 73 & 100 & 153 & 161 & 83 & 110 & 107 \\
\hline
\end{tabular}

\section{South EAST ASIA}

Available statistics (Tables XVIII-XIX) from South East Asia before 1945 are defective. With reference to those of that year, it is necessary to state:

(a) owing to a change of documentation comparable January figures are not available;

(b) no adjustment with respect to differential local risk is possible on the basis of information received by the War Office. 

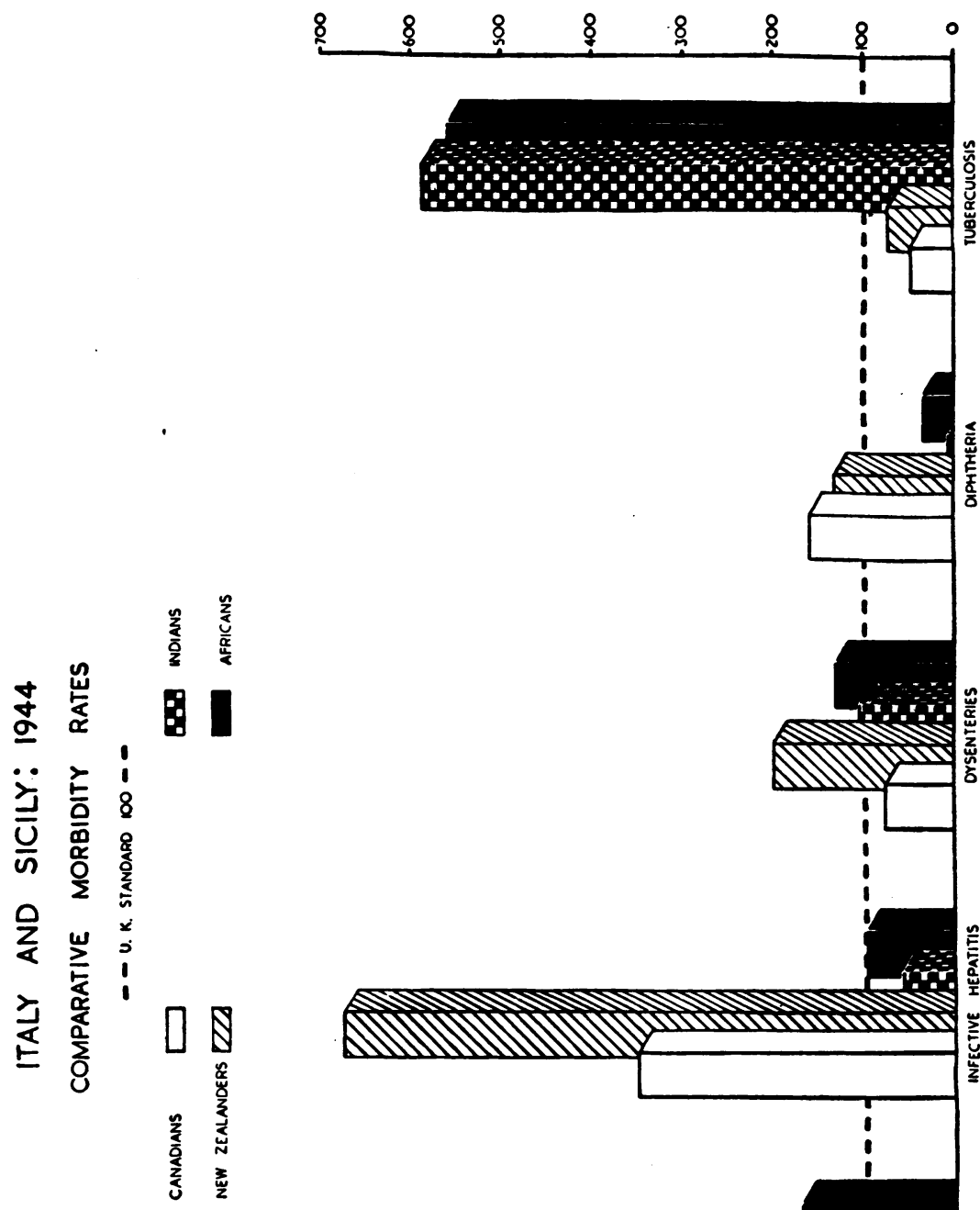

잉

ज्ञ

. 
TABLE XVIII

Relative Rates of Cases admitred to all Medical Units in Alfsea; 1945

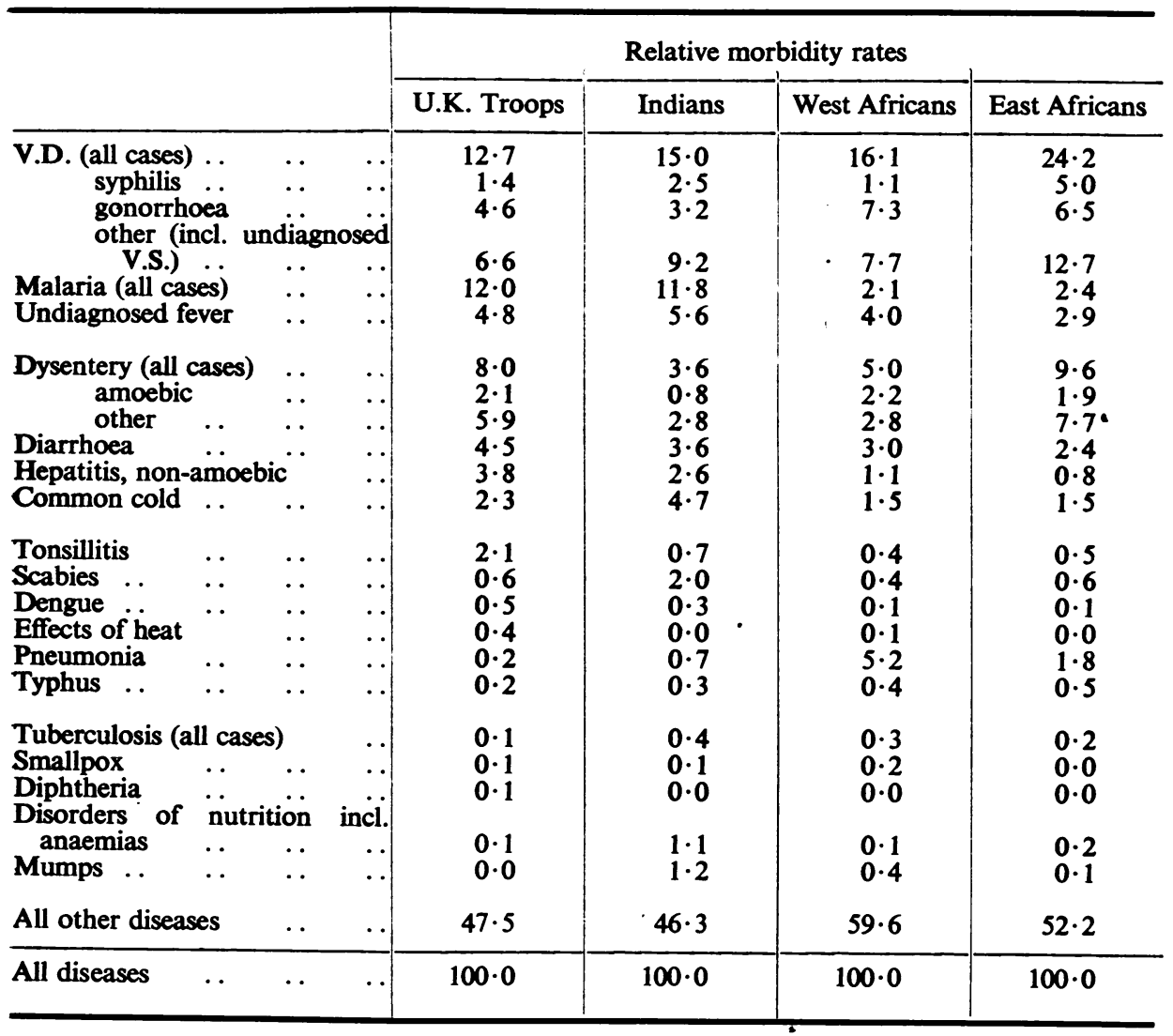

The figures for 1945 are of special interest in so far as they permit the separation of African personnel into two categories respectively recruited from British West and British East Africa. The data are consonant with those of the Middle East in so far as they show that:

(i) Both African and Indian troops are less prone than U.K. troops to malaria, diphtheria, and tonsillar infections;

(ii) Both Indian and African troops are conspicuously more prone than are U.K. troops to mumps;

(iii) African troops were more prone to pneumonia than were U.K. troops.

An additional fact which emerges is that Africans and Indians were much less prone to dengue. The most striking discrepancy between experience in this theatre and elsewhere is the comparatively low venereal disease rate of Africans. 
1
0
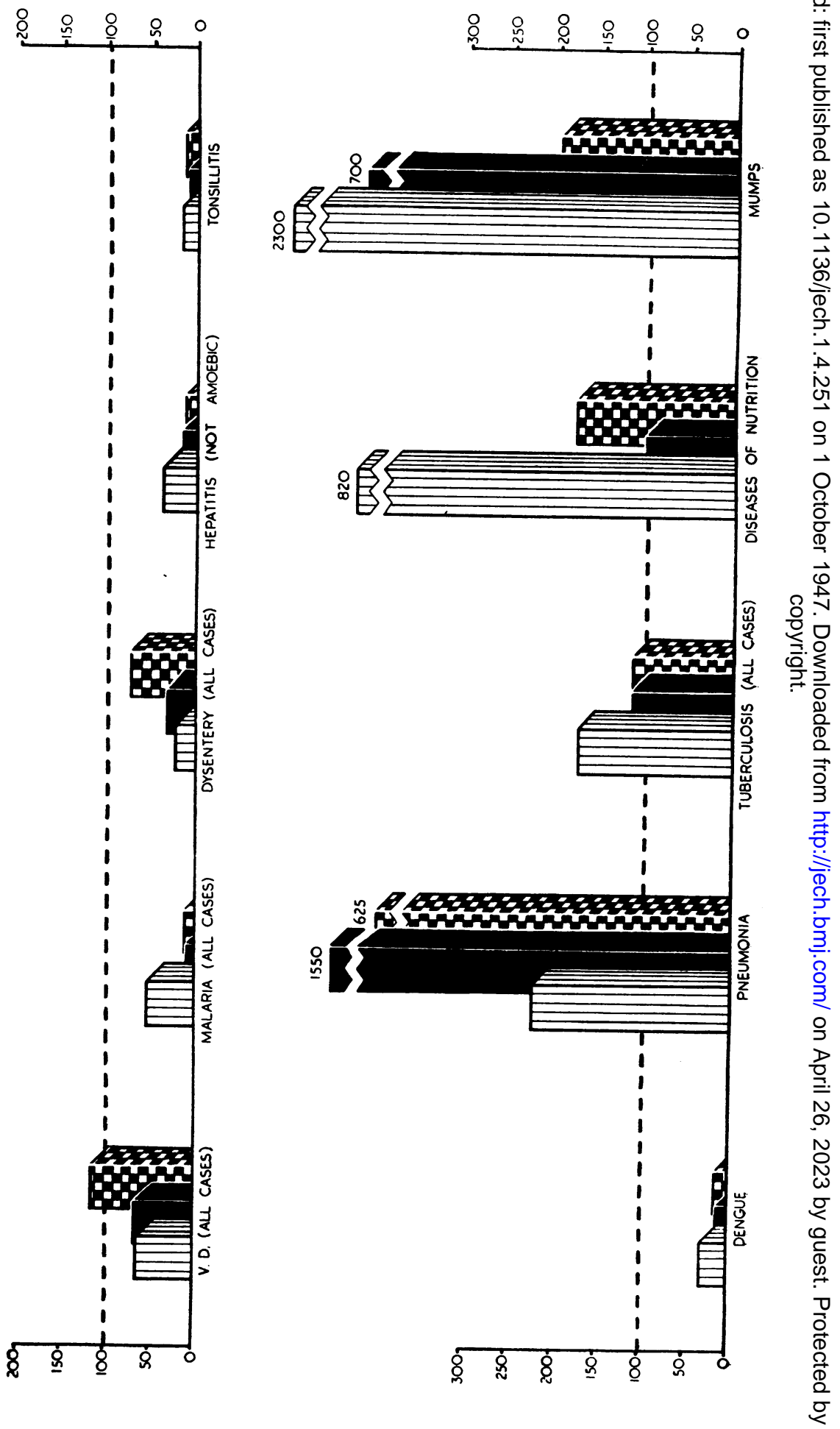
TABLE XIX

Comparative Rates of Cases admitted to all Medical Units in Alfsea; 1945

\begin{tabular}{|c|c|c|c|c|c|}
\hline & & \multicolumn{4}{|c|}{ Comparative morbidity rates } \\
\hline & & U.K. Troops & Indians & West Africans & East Africans \\
\hline $\begin{array}{l}\text { V.D. (all cases) ... } \\
\text { syphilis .. } \\
\text { gonorrhoea } \\
\text { other (incl. und }\end{array}$ & $\begin{array}{ll}\ldots & \ldots \\
\ldots & \ldots \\
\text { diagnosed }\end{array}$ & $\begin{array}{l}100 \\
100 \\
100\end{array}$ & $\begin{array}{l}64 \\
96 \\
38\end{array}$ & $\begin{array}{l}66 \\
38 \\
82\end{array}$ & $\begin{array}{r}116 \\
209 \\
85\end{array}$ \\
\hline $\begin{array}{l}\text { V.S.) } \\
\text { Malaria (all cases) } \\
\text { Undiagnosed fever }\end{array}$ & $\begin{array}{ll}\cdots & \cdots \\
\cdots & \cdots \\
. & \cdots\end{array}$ & $\begin{array}{l}100 \\
100 \\
100\end{array}$ & $\begin{array}{l}76 \\
54 \\
62\end{array}$ & $\begin{array}{r}60 \\
9 \\
43\end{array}$ & $\begin{array}{r}117 \\
12 \\
37\end{array}$ \\
\hline $\begin{array}{l}\text { Dysentery (all cases) } \\
\text { amoebic } \\
\text { other } \\
\text { Diarrhoea } \\
\text { Hepatitis, non-amoebi } \\
\text { Common cold .. }\end{array}$ & $\begin{array}{l}\cdots \\
\cdots \\
\cdots \\
\cdots \\
\ldots\end{array}$ & $\begin{array}{l}100 \\
100 \\
100 \\
100 \\
100 \\
100\end{array}$ & $\begin{array}{r}24 \\
21 \\
26 \\
44 \\
38 \\
110\end{array}$ & $\begin{array}{l}33 \\
55 \\
25 \\
34 \\
16 \\
34\end{array}$ & $\begin{array}{l}73 \\
55 \\
79 \\
32 \\
13 \\
40\end{array}$ \\
\hline $\begin{array}{ll}\text { Tonsillitis } & \ldots \\
\text { Scabies .. } & . . \\
\text { Dengue . } & . . \\
\text { Effects of heat } & \\
\text { Pneumonia } & . . \\
\text { Typhus .. } & .\end{array}$ & $\begin{array}{l}\cdots \\
\cdots \\
\cdots \\
\cdots \\
\cdots\end{array}$ & $\begin{array}{l}100 \\
100 \\
100 \\
100 \\
100 \\
100\end{array}$ & $\begin{array}{r}17 \\
174 \\
32 \\
0 \\
225 \\
108\end{array}$ & $\begin{array}{r}11 \\
35 \\
13 \\
8 \\
1,550 \\
125\end{array}$ & $\begin{array}{r}15 \\
63 \\
16 \\
8 \\
625 \\
175\end{array}$ \\
\hline $\begin{array}{l}\text { Tuberculosis (all cases, } \\
\text { Smallpox } \\
\text { Diphtheria } \\
\text { Disorders of } \\
\text { anaemias } \\
\text { Mutrit } \\
\text { Mumps .. } \\
\text {... }\end{array}$ & $\begin{array}{cc} & \ldots \\
. & \cdots \\
. . & . \\
\ldots & \text { incl. } \\
\ldots & .\end{array}$ & $\begin{array}{l}100 \\
100 \\
100 \\
100 \\
100\end{array}$ & $\begin{array}{r}175 \\
43 \\
0 \\
\\
820 \\
2,300\end{array}$ & $\begin{array}{r}113 \\
100 \\
0 \\
100 \\
700\end{array}$ & $\begin{array}{r}113 \\
29 \\
0 \\
180 \\
200\end{array}$ \\
\hline All diseases & . & 100 & 54 & 52 & 61 \\
\hline
\end{tabular}

\section{Discussion}

Diseases to which troops of European stock proved to be more susceptible than either Asiatics or Africans were mainly such as commonly occur in tropical or semi-tropical habitats and are rare or unknown in Britain. Such are malaria, sandfly fever, dengue, relapsing fever, the enteric group, and amoebic dysentery. Two others call for comment. In all theatres Africans and Asiatics alike withstood outbreaks of diphtheria, to which U.K. troops succumbed with much greater frequency. A possible and likely explanation of this is not far to seek. Although cutaneous, in contradistinction to faucial, diphtheria is rare in Britain, diphtheritic sores are common in hot countries. It is therefore possible that this differential arises from the existence of exposure of Asiatics and Africans during childhood to greater opportunities of immunization.

In any case, we have to remember that our data refer exclusively to an age group which is adult. Hence we have no reason to suppose that differentials of this class 
signify innate differences with respect to the resistance of the populations concerned, that is, differences brought about by generations of selection in the genetic sense of the term. Confident assertions of this sort current in writings of eugenists, in particular with respect to the high resistance of Africans to malaria, are unwarranted. We shall not be in a position to interpret the malaria differential until we know far more about the effects of exposure to infection in early childhood, both with respect to the severity of an initial attack and with respect to what immunity it may confer.

In this context, infective hepatitis is more difficult to place than is diphtheria. Its aetiology is still open to dispute and its differential diagnosis is a comparatively recent accomplishment. Consequently, we have little information about the extent to which it is endemic in Asiatic or African communities. We may hope that attention focused by wartime experience on its prevalence among European troops abroad may henceforth make medical experts in tropical and sub-tropical countries more alert to its occurrence. Other communicable diseases mentioned above are such as are propagated by insect vectors, by droplet infection, by contaminated food, and by drinking water. It is noteworthy that U.K. troops did not succumb to putatively contagious diseases, for example yaws and leprosy, or to helminthiases. endemic in the territories where they served.

Of diseases to which both Asiatics and Africans succumbed more readily than troops of European stock, mumps is the most conspicuous. Pneumonia and tuberculosis are also worthy of mention, the latter with a relatively high fatality rate as well as a relatively high incidence. West Africans appear to have little resistance to chickenpox, perhaps because this disease is rare in their native habitat. In contradistinction to mumps and chickenpox, outbreaks of measles did not conspicuously single out Africans or Asiatics for attack. In the absence of reliable statistics of disease among the civilian populations of British colonies, it would be premature to discuss the significance of these differentials. We can merely hope that the Colonial Office will eventually fall into step with the Army Council by setting up machinery to supply information necessary alike to the advancement of science and to discharge of the obligations of our trusteeship.

The high relative incidence of venereal disease among African troops calls for special comment vis-a-vis earlier remarks on the venereal disease rate among troops stationed in West Africa. In 1945 the ratio of the equivalent annual rate of Africans to that of U.K. troops in M.E.F. was 3.1, and in West Africa 5.9. In Alfsea, the corresponding ratios for West Africans and East Africans were 0.7 and 1.2.' In C.M.F. during 1944 the ratio was $1 \cdot 7$. The annual rates of all venereal diseases per thousand U.K. troops in 1945 were: West Africa 82.1; Alfsea $92.5 ;$ C.M.F. 68.3; M.E.F. 30.5 . In round figures we may therefore say that the venereal disease rate among West Africans in their own habitat was more than four times as high as that of Africans in any other theatre. Clearly, it is not plausible to attribute this excessively high venereal disease rate among African troops to conditions of Army life alone. We have to seek for an 
explanation in local conditions. With fullest recognition of the fact that West Africa was not a static theatre, we are driven to the conclusion that official statistics grossly under-estimate the prevalence of venereal disease in the civilian population.* The consistently low overall figure for troops in the Middle East is undoubtedly attributable to the energetic preventive policy pursued by the Directorate of Hygiene at G.H.Q. Cairo.

Grateful acknowledgment is due to the following who have kindly read the draft of this communication and have made helpful suggestions thereon: Brigadier A. E. Richmond, Professor W. Melville Arnott, Professor T. McKeown, and Lt.-Col. C. C. M. James.

\section{REFERENCES}

Annotation (1947). Lancet, 1, 684.

Hailey, Lord (1938). "An African Survey", 1120.

Hogben, L., and Johnstone, M. M. (1947). Brit. J. soc. Med., 1, 149.

Willcox, R. R. (1946). Brit. J. vener. Dis., 22, 63.

* Referring further afield, to Uganda, Lord Hailey (An African Survey, p. 1,120) states: “ in 1908 Colonel F. J. Lambkin reported that in certain areas the incidence of syphilis was as high as 90\%. Three officers of the Royal Army Medical Corps were at once sent to work on this disease, and from them as a nucleus the Uganda Government Medical Service rapidly developed.' 